TITLE:

\title{
A sulfoximine-based inhibitor of human asparagine synthetase kills l-asparaginase-resistant leukemia cells.
}

\section{AUTHOR(S):}

Ikeuchi, Hideyuki; Ahn, Yong-Mo; Otokawa, Takuya; Watanabe, Bunta; Hegazy, Lamees; Hiratake, Jun; Richards, Nigel G J

\section{CITATION:}

Ikeuchi, Hideyuki ...[et al]. A sulfoximine-based inhibitor of human asparagine synthetase kills l-asparaginase-resistant leukemia cells.. Bioorganic \& medicinal chemistry 2012, 20(19): 5915-5927

\section{ISSUE DATE:}

2012-10

URL:

http://hdl.handle.net/2433/160385

\section{RIGHT:}

(C) 2012 Elsevier Ltd.; This is not the published version. Please cite only the published version.; この論文は出版社版でありません。引用の際に は出版社版をご確認ご利用ください。 


\title{
A Sulfoximine-Based Inhibitor of Human Asparagine Synthetase Kills L-Asparaginase-Resistant Leukemia Cells
}

\author{
Hideyuki Ikeuchi ${ }^{\text {a }}$, Yong-Mo Ahn ${ }^{\mathrm{b}}$, Takuya Otokawa ${ }^{\mathrm{a}}$, Bunta Watanabe ${ }^{\mathrm{a}}$, \\ Lamees Hegazy $^{\text {b }}$, Jun Hiratake ${ }^{\mathrm{a} *}$, Nigel G. J. Richards ${ }^{\mathrm{b} *}$ \\ a Institute for Chemical Research, Kyoto University, Uji, Kyoto 611-0011, Japan \\ ${ }^{\mathrm{b}}$ Department of Chemistry, University of Florida, Gainesville, FL 32611-7200, USA
}

KEYWORDS: Acute lymphoblastic leukemia; Asparagine synthetase; Transition-state analogue inhibitor; Sulfoximine; Structure-activity relationship; MOLT-4 leukemia cell line; L-Asparagine amidohydrolase; Cell death (Jun Hiratake); phone: +1 352392 3601; fax: +1 352846 2095; E-mail address: richards@qtp.ufl.edu (Nigel G. J. Richards) 


\section{Abstract}

An adenylated sulfoximine transition-state analogue 1, which inhibits human asparagine synthetase (hASNS) with nanomolar potency, has been reported to suppress the proliferation of an L-asparagine amidohydrolase (ASNase)-resistant MOLT-4 leukemia cell line (MOLT-4R) when L-asparagine is depleted in the medium. We now report the synthesis and biological activity of two new sulfoximine analogues of $\mathbf{1}$ that have been studied as part of systematic efforts to identify compounds with improved cell permeability and/or metabolic stability. One of these new analogues, an amino sulfoximine 5 that having no net charge at cellular $\mathrm{pH}$, is a better hASNS inhibitor $\left(K_{\mathrm{I}}^{*}=8 \mathrm{nM}\right)$ than 1 and suppresses proliferation of MOLT-4R cells at 10 -fold lower concentration $\left(\mathrm{IC}_{50}=0.1 \mathrm{mM}\right)$. More importantly, and in contrast to the lead compound $\mathbf{1}$, the presence of sulfoximine $\mathbf{5}$ at concentrations above $0.25 \mathrm{mM}$ causes the death of MOLT-4R cells even when ASNase is absent in the culture medium. The amino sulfoximine 5 exhibits different dose-response behavior when incubated with an ASNase-sensitive MOLT-4 cell line (MOLT-4S), supporting the hypothesis that sulfoximine 5 exerts its effect by inhibiting hASNS in the cell. Our work provides further evidence for the idea that hASNS represents a chemotherapeutic target for the treatment of leukemia, and perhaps other cancers such as those of the ovary and prostate. 


\section{Introduction}

Substantial success has been achieved in the clinical treatment of acute lymphoblastic leukemia (ALL), which is the most common form of childhood cancer. ${ }^{1}$ A majority of current protocols include the enzyme L-asparagine amidohydrolase (ASNase), ${ }^{2,3}$ which catalyzes the hydrolysis of L-asparagine to yield L-aspartate and ammonia. ${ }^{4,5}$ On the other hand, ASNase has a relatively narrow therapeutic index with up to two thirds of patients exhibiting a hypersensitive immune response. ${ }^{6,7}$ Another significant problem with the use of ASNase in chemotherapy is that $10-12 \%$ of patients who initially go into remission undergo subsequent relapse due to the emergence of ASNase-resistant leukemic blasts. ${ }^{8}$ The molecular basis for the sensitivity of leukemic blasts to ASNase remains undetermined, in part because of the absence of small molecules that can be used to probe the cellular mechanisms that give rise to ASNase sensitivity and the suppression of cell proliferation. One widely-accepted hypothesis postulates that ASNase sensitivity is associated with a requirement for malignant lymphocytes to import L-asparagine from their surroundings. ${ }^{9,10}$ Although this idea has generated some controversy, there have been reports of a correlation between the appearance of ASNase resistance and the up-regulation of glutamine-dependent asparagine synthetase (ASNS), ${ }^{11-13}$ which mediates de novo asparagine biosynthesis (Scheme 1). ${ }^{9,14}$ In vitro adaptive studies employing U937 cells in which ASNase-sensitive cells became resistant by persistent exposure to sub-lethal doses of ASNase have also been reported. ${ }^{15}$ Perhaps the strongest evidence for the importance of ASNS expression has been obtained, however, from experiments in which an ASNase-sensitive 
MOLT-4 (MOLT-4S) leukemia cell line was rendered resistant to the presence of ASNase in the growth medium merely by transformation with a plasmid from which the hASNS gene was constitutively expressed.15 The likely importance of human ASNS (hASNS) in other forms of cancer is suggested by recent work showing that this enzyme is a biomarker for ovarian cancer. ${ }^{16,17}$ More direct methods for examining the role of ASNS expression in ASNase-resistance, such as siRNA knockdown experiments on ASNase-resistant MOLT-4 (MOLT-4R) leukemia cell lines have, to the best of our knowledge, not yet been reported. However, very recent work has shown that siRNA knockdown of hASNS expression inhibited the growth of both androgen-responsive lymph node and prostate cancer cell lines, and cells isolated from a castration- resistant (MDA PCa 180-30) prostate cancer xenograft when grown in media depleted of L-asparagine. ${ }^{18}$

In an important step towards understanding whether ASNase-resistance arises from an increased ability of leukemic blasts to up-regulate L-asparagine biosynthesis, we recently showed that the adenylated sulfoximine $\mathbf{1}$ (Figure 1) ${ }^{19}$, which is a stable analogue of the transition-state for ammonia addition to $\beta$-aspartyl-AMP intermediate (Scheme 1), ${ }^{18}$ inhibited hASNS with nanomolar potency. ${ }^{20}$ More importantly, sulfoximine 1 suppresses the proliferation of ASNase-resistant MOLT-4 (MOLT-4R) cells in a dose-dependent manner, but only at 100-1000 $\mu \mathrm{M}$ concentrations and when L-asparagine is depleted in the external medium by ASNase.$^{20}$ The need to use high concentrations of sulfoximine 1 to suppress cell proliferation is likely due to ionizable groups on the molecule that result in an overall negative charge at cellular $\mathrm{pH}$ and limit cell permeability (Figure 1). Experiments 
using compounds $\mathbf{2}$ and $\mathbf{3}$ (Figure 1), in which the phosphate moiety is replaced by a sulfamide or sulfamate functional group, however, revealed that the negatively charged phosphate is essential for hASNS inhibition. ${ }^{21}$ Examination of the crystal structure of Escherichia coli asparagine synthetase B $(\mathrm{AS}-\mathrm{B})^{22}$ reveals a critical electrostatic interaction between the phosphate moiety of inhibitor $\mathbf{1}$ and a conserved, catalytically important lysine (Lys-449 and Lys-466 for AS-B and hASNS, respectively). ${ }^{21}$ In support of this hypothesis, the $N$-acylsulfamide 4 (Figure 1), in which dissociation of an acidic NH proton produces a resonance-stabilized negative charge on the sulfamate oxygen, inhibits hASNS with micromolar potency. ${ }^{23}$

We now report syntheses of two new adenylated sulfoximines 5 and 6 (Figure 1), in which the $\alpha$-carboxy and $\alpha$-amino groups are removed from the hASNS inhibitor $\mathbf{1}$, respectively. These changes have allowed us to not only elucidate the relative contributions of these ionizable groups to the affinity of the parent sulfoximine $\mathbf{1}$ for the hASNS synthetase active site but also examine how overall molecular charge might be correlated with sulfoximine bioavailability and cell-based activity. The amino sulfoximine $\mathbf{5}$, which has no net charge at cellular $\mathrm{pH}$, is a better hASNS inhibitor $\left(K_{\mathrm{I}}^{*}=\right.$ $8 \mathrm{nM})$ and suppresses proliferation of MOLT-4R cells at 10 -fold lower concentration $\left(\mathrm{IC}_{50}=0.1\right.$ $\mathrm{mM}$ ) than sulfoximine 1. Moreover, in an exciting observation for the investigation of molecular mechanisms underlying the sensitivity of leukemic blasts to ASNase, sulfoximine $\mathbf{5}$ induces cell death in MOLT-4R cells at sub-millimolar concentrations irrespective of the presence of ASNase in the external medium. Although the exact mechanism by which sulfoximine $\mathbf{5}$ induces cell death 
remains to be established, MOLT-4R and MOLT-4S cells exhibit different dose-response behaviors when incubated with sulfoximine $\mathbf{5}$, supporting the hypothesis that sulfoximine $\mathbf{5}$ exerts its effect by inhibiting hASNS in the cell.

\section{Chemistry}

Synthetic routes to adenylated sulfoximines $\mathbf{5}$ and $\mathbf{6}$ were based on that used to prepare the parent compound 1. ${ }^{19}$ Given that the negatively charged 5'-phosphate of adenylic acid is essential for tight binding to hASNS, this moiety was attached by N-phosphorylation of pre-formed sulfoximines 10 and 16, themselves prepared from the corresponding sulfoxides 9 (Scheme 2) and 15 (Scheme 3), respectively. Despite attempts to perform the efficient imination of these sulfoxides in a safe manner, for example by using a rhodium-catalyzed reaction with trifluoroacetamide and $\mathrm{PhI}(\mathrm{OAc})_{2},{ }^{23}$ the best reagent for preparing the unsubstituted sulfoximines $\mathbf{1 0}$ and $\mathbf{1 6}$ proved to be $O$-mesitylsulfonylhydroxylamine (MSH) ${ }^{25,26}$ [Caution: $\mathrm{MSH}$ is potentially explosive and extreme care must be taken in handling and storing this hazardous reagent particularly in large amounts (> ca. $1 \mathrm{~g})]$. The need to perform the imination using MSH constrained the choice of protecting groups for sulfoxides 9 and $\mathbf{1 5}$ because strongly acidic mesitylsulfonic acid is formed as a by-product of the reaction. We therefore selected 2,2,2-trichloroethyl carbamate group (Troc) for masking the $\alpha$-amino group, and allyl esters to protect the $\alpha$-carboxy and the phosphate groups. 
$\mathrm{N}$-adenylation of sulfoximines $\mathbf{1 0}$ and $\mathbf{1 6}$ was carried out by reaction with protected adenosyl phosphite 11 under standard phosphoramidite coupling conditions using tetrazole as a catalyst. ${ }^{26}$ Formation of the acid sensitive $\mathrm{P}-\mathrm{N}$ bond in the phosphoramidate intermediate under these conditions requires the exclusion of moisture, ${ }^{28}$ and this was accomplished by running the coupling reaction in anhydrous $\mathrm{CH}_{3} \mathrm{CN}$ over $4 \AA$ molecular sieves. The adenylated sulfoximines $\mathbf{1 2}$ and $\mathbf{1 7}$ could then be obtained, in good yields, albeit as a 1:1 mixture of diastereoisomers at the sulfur stereogenic center, after in situ oxidation of the P(III) intermediates formed in the initial coupling reaction. Interestingly, the $\mathrm{P}-\mathrm{N}$ bond, once formed with sulfoximine nitrogen $(\mathrm{S}=\mathrm{N})$, was hydrolytically stable even under highly acidic conditions (Scheme 2 and 3), probably because of the weak basicity of the sulfoximine nitrogen. Chromatographic conditions to separate the diastereoisomers of sulfoximines 5 and $\mathbf{6}$ (or their precursors $\mathbf{1 3}$ and 18) could not be identified.

\section{Enzyme Assays}

With sulfoximines 5 and $\mathbf{6}$ in hand, we investigated their ability to inhibit hASNS following well-established steady-state kinetic assays.$^{20,29}$ Hence, the effect of sulfoximines $\mathbf{5}$ and $\mathbf{6}$ (each as a mixture of two diastereoisomers) on hASNS-catalyzed asparagine synthesis was assayed by measuring the rate of inorganic pyrophosphate $\left(\mathrm{PP}_{\mathrm{i}}\right)$ production.$^{30}$ The recombinant human enzyme was obtained by expression in $S f 9$ insect cells, and purified by metal-affinity chromatography, as reported previously. ${ }^{31}$ All kinetic assays employed diastereoisomeric mixtures of $\mathbf{5}$ and $\mathbf{6}$ in which 
each of the sulfoximines was a 1:1 mixture of epimers at the sulfur stereogenic center. As discussed in detail elsewhere ${ }^{20,32,33}$ considerable evidence exists for a strong stereochemical dependence of any tight-binding inhibition that is observed for functionalized sulfoximines. ${ }^{34,35}$ All of the inhibition constants derived from steady-state kinetic experiments are based on the assumption that only a single diastereoisomer of each functionalized sulfoximine binds to, and inhibits, hASNS without interference with by the other diastereoisomer. When recombinant hASNS was incubated with ATP, L-aspartate, $\mathrm{MgCl}_{2}$ and either glutamine (Figure 2A) or ammonia (Figure 2B) as a nitrogen source, the amino sulfoximine $\mathbf{5}$ acted as a slow-onset, tight-binding inhibitor. ${ }^{36}$ As in previous studies, ${ }^{20,21}$ the kinetic data were analyzed using a simple model in which the functionalized sulfoximine competes with ATP for free hASNS and showed that $\mathbf{5}$ was a more potent hASNS inhibitor than $\mathbf{1}$, with an overall inhibition constant $\left(K_{\mathrm{i}}^{*}\right)$ of $8 \mathrm{nM}$ when L-glutamine was used as the nitrogen source (Table 1). The $K_{\mathrm{I}}^{*}$ value for sulfoximine 5 (uncorrected on the basis of an assumed concentration of the active isomer) was increased four-fold under the same conditions when ammonia was employed in place of L-glutamine (Table 1), suggesting that inhibitor 5 binds strongly to an enzyme conformation in which the N-terminal glutaminase site is occupied by either substrate glutamine or a thioester intermediate. ${ }^{11,37,38}$ Experiments examining the effect of various nucleotides on the glutaminase activity of Escherichia coli asparagine synthetase B (AS-B) are consistent with conformational cross-talk between the glutaminase and synthetase active sites of the enzyme. ${ }^{39}$ Future efforts to establish which diastereoisomer of $\mathbf{5}$ binds to the hASNS synthetase site with 
highest affinity will require preparing intermediate sulfoxide $\mathbf{9}$ in optically pure form, perhaps by the asymmetric oxidation of sulfide $\mathbf{8}^{39}$ In contrast to the improved activity of amino sulfoximine $\mathbf{5}$, the carboxy sulfoximine 6 was a relatively poor hASNS inhibitor (Figure 3), exhibiting $K_{\mathrm{I}}^{*}$ values of only $800 \mathrm{nM}$ and $300 \mathrm{nM}$ when the nitrogen source was glutamine or ammonia, respectively. Control experiments established that neither compound inhibited the coupling enzymes in the pyrophosphate reagent used for the continuous assay (data not shown).

Given the close resemblance of all three sulfoximine derivatives $\mathbf{1}, \mathbf{5}$, and $\mathbf{6}$, and their conformational flexibility, we anticipated that the inhibitory diastereoisomers of all three compounds would bind in a similar fashion within the synthetase active site of hASNS. This idea was qualitatively investigated by positioning the diastereoisomers of $\mathbf{5}$ and $\mathbf{6}$ within a model of Escherichia coli AS-B,${ }^{20}$ which we have developed from X-ray structural information (Figure 4A). ${ }^{21}$ Models (AS-B/glutamine/inhibitor/ $\mathrm{Mg}^{2+}$ ) were constructed for each of the hASNS inhibitors (two diastereoisomers of each sulfoximine 5 and 6), and placed within an octahedral box of TIP3 water molecules. ${ }^{41}$ Subsequent energy minimization was performed on the solvated system using the CHARMM27 force field, ${ }^{42}$ augmented by parameters for the sulfoximine moiety obtained using the CGenFF software package..$^{43}$ In these models $\mathrm{Mg}(\mathrm{II})$ was bound at its usual site, i.e. coordinated to the side chain of Asp-238 (AS-B numbering), and we assumed that neither 5 nor $\mathbf{6}$ would be bound at the same time as inorganic pyrophosphate $\left(\mathrm{PP}_{\mathrm{i}}\right)$. This computational strategy provided a qualitative understanding of differences in the interaction of conserved residues in the synthetase active site with 
functional groups on the diastereoisomers of sulfoximine 5 (Figures 5A and 5B) and $\mathbf{6}$ (Figures 5C and 5D). For example, the amino group in both diastereoisomers of $\mathbf{5}$ forms a complementary interaction with Glu-348 (a residue that has been shown to play a role in mediating the formation of the $\beta$-aspartyl-AMP intermediate ${ }^{44}$ ), and the critical electrostatic interaction between the phosphate group and Lys-449 is maintained in both complexes. ${ }^{21}$ Altering the stereochemistry at the stereogenic sulfur center does, however, change the interaction of the amino group with other carboxylate side chains (Figures 5A and 5B). On this point, we note that the diastereoisomer in which the sulfoximine has an $(R)$-configuration (Figure 5A) represents the structure in which the methyl substituent on sulfur points towards the ammonia tunnel present in the enzyme. ${ }^{22,45}$ It is believed that the methyl group attached to the sulfur atom mimics the ammonia molecule as it undergoes reaction with $\beta$-aspartyl-AMP (Scheme 1). ${ }^{20}$ In contrast, the absence of the $\alpha$-amino group in sulfoximine $\mathbf{1}$ (giving the carboxy sulfoximine 6) results in a reorientation of the synthetase site side chains so that the carboxylate of the diastereoisomer of $\mathbf{6}$ that is likely to represent the true inhibitor, based on the orientation of the methyl group connected to the stereogenic $(R)$-sulfur center, interacts with a conserved lysine residue (Lys-376 in AS-B) (Figure 5C). The Lys-449/phosphate interaction is also maintained in this model of the complex and the side chain of Glu-348 re-orients to form a hydrogen bond to the 2'-hydroxy group on ribose. The hypothesis that the other diastereoisomer of 6 is inactive is supported by (i) the possible interaction of Lys-449 with the carboxylate group rather than the 5'-phosphate of sulfoximine 6, and (ii) a reorientation of Glu-348 to form a hydrogen bond with 
Ser-346 rather than the ribose ring, presumably due to electrostatic repulsion with the carboxylate of sulfoximine 6 (Figure 5D).

These qualitative differences do not seem to provide an adequate explanation as to why the putative active diastereoisomers of 5 and $\mathbf{6}$ (Figures 5A and 5C) should exhibit such large differences in affinity (Table 1). We therefore examined alternate hypotheses given that sulfoximine $\mathbf{5}$ has no net charge while 6 is present as a dianion under the conditions of our assay ( $\mathrm{pH} 8$ ). First, we calculated the electrostatic potential of the free enzyme in aqueous solution by solving the Poisson-Boltzmann equation, ${ }^{46}$ using the algorithms implemented in the APBS software package. ${ }^{47,48}$ The protein structure used in these calculations was that obtained by removing $\beta$-aspartyl-AMP and inorganic pyrophosphate from our original model of the AS-B/L-glutamine/ $\beta$-aspartyl-AMP/MgPP ${ }_{\mathrm{i}}$ complex. $^{21}$ These calculations show that a large portion of the synthetase active site surface carries a negative electrostatic potential with only two specific regions of positive potential to stabilize the carboxylate and phosphate moieties of the $\beta$-aspartyl-AMP intermediate (Figure 4B). Thus the differential affinities of 5 and $\mathbf{6}$ might be associated with their overall charge. In addition, differences in the initial dissociation constants $\left(K_{\mathrm{I}}\right)$ for $\mathbf{5}$ and $\mathbf{6}$ (Table 1) could also arise from desolvation effects, ${ }^{49,50}$ that is, if the dianion of sulfoximine $\mathbf{6}$ is better solvated in water than $\mathbf{5}$ then its relative affinity for the synthetase site will be decreased. Definitive insights await the characterization of additional sulfoximine derivatives using both experimental and quantitative computational methods. 


\section{Cell based assays}

Given that the amino sulfoximine 5 inhibited hASNS with low nanomolar affinity in assays where L-glutamine was the nitrogen source, we investigated whether this compound could also stop the growth of the MOLT-4R leukemia cell line. ${ }^{51-53}$ We note that this line was obtained by growing MOLT-4S cells in media containing increasing amounts of the enzyme ASNase, and not by plasmid transformation and constitutive expression of the ASNS gene. As in our experiments on the biological activity of sulfoximine $1,{ }^{20}$ these MOLT-4R cells were transferred to growth medium containing 10-1000 $\mu \mathrm{M}$ concentrations of the sulfoximine 5 and their survival after 48 hours was assayed using a dye-based method to estimate changes in the number of viable cells. ${ }^{54}$ Once again, micro- to millimolar concentrations of the hASNS inhibitor were used because of concerns about the cell permeability of compound. As expected from our previous work, ${ }^{20}$ sulfoximine $\mathbf{5}$ showed a weak dose-dependent ability to suppress MOLT-4R proliferation at concentrations up to $130 \mu \mathrm{M}$ in the absence of ASNase (Figure 6A). This represents an approximate 7-fold gain in suppression activity relative to sulfoximine $\mathbf{1}$ in the presence of ASNase, ${ }^{21}$ suggesting an increased bioavailability of sulfoximine 5 and an intracellular interaction with hASNS. In an important contrast to our findings for sulfoximine 1, however, the number of viable MOLT-4R cells was markedly decreased when $\mathbf{5}$ was present at $250 \mu \mathrm{M}$ concentration, and this compound caused the death of almost all the MOLT-4R cells at higher concentrations $(>500 \mu \mathrm{M})$. These biological effects could be amplified to a small extent by depleting asparagine in the culture medium by the addition of $1 \mathrm{U} / \mathrm{mg}$ ASNase; cell 
proliferation was suppressed when 5 was added at $130 \mu \mathrm{M}$ concentration (Figure 6B). Furthermore the ability of 5 to cause cell death was also enhanced with $250 \mu \mathrm{M}$ of compound $\mathbf{5}$ being sufficient to kill almost all the MOLT-4R cells (Figure 6B). However, the magnitude of the shift in dose response for the activity of $\mathbf{5}$ with the MOLT-4R cell line in the presence and absence of ASNase was much smaller than that observed for sulfoximine $1 .^{20}$ It is possible that this observation is associated with the impact of ASNase on the ability of the cells to proliferate. Thus, careful examination of the data suggests that compound $\mathbf{5}$ does have a slightly greater ability to reduce proliferation when present at $0.13 \mathrm{mM}$, but this is masked by the significant reduction in cell growth caused by deletion of asparagine in the medium. At concentrations of $0.06 \mathrm{mM}$, and below, 5 seems to have essentially no effect whether ASNase is present or not. While this observation might argue for the hypothesis that 5 must be present at $0.1 \mathrm{mM}$ before being able to enter the cells, it could also reflect the fact that cells with a much reduced rate of proliferation require much lower levels of endogenous/exogenous asparagine to survive. In order to evaluate whether these biological effects were correlated with the presence of hASNS in the MOLT-4R cell lines, we incubated sulfoximine $\mathbf{5}$ with MOLT-4S cells derived from the same parent MOLT-4 cell line. Prior work has established that MOLT-4S cells express hASNS in considerably lower amounts than those found in MOLT-4R cells ${ }^{5,55}$ which means that higher concentrations of $\mathbf{5}$ should be required to suppress the proliferation of the MOLT-4S cells. In fact, compound 5 appeared to have little effect on the MOLT-4S cells at concentrations below $130 \mu \mathrm{M}$, and exhibited lower activity in suppression of cell proliferation at 
concentrations of $250 \mu \mathrm{M}$ and $500 \mu \mathrm{M}$ (Figure 6C), when compared with the results of experiments using the MOLT-4R cells (Figure 6A). These results provide a support for a possible link between hASNS activity and cell death: the MOLT-4R cell line is highly dependent on its own hASNS activity for access to L-asparagine supply and is accordingly more susceptible to inhibition of this enzyme. However, millimolar concentrations of $\mathbf{5}$ once again caused significant levels of MOLT-4S cell death, raising the possibility that this compound binds to other cellular targets at high concentration. Given that the parent sulfoximine 1 can also inhibit the ammonia-dependent Escherichia coli AS-A, ${ }^{19}$ which is evolutionarily related to aspartyl tRNA synthetase, ${ }^{56,57}$ it is possible that $\mathbf{5}$ might be capable of binding to, and inhibiting, human aspartyl-tRNA synthetase. Further work, perhaps using sulfoximines functionalized with adenosine mimics that bind specifically to hASNS, will be required to rule out the latter possibility. 


\section{Conclusions}

We have identified the first functionalized sulfoximine (5) that inhibits the glutamine-dependent synthetase activity of human ASNS with low nanomolar potency. As judged by its ability to suppress the proliferation of an ASNase-resistant MOLT-4 cell line at reduced concentrations compared to the parental sulfoximine 1 (Figure 1), this compound may possess better cell permeability because of its zero net charge at neutral $\mathrm{pH}$. The improved activity of $\mathbf{5}$ might also arise from its increased stability to metabolic transformations within the cell, such as depurination or hydrolysis, but the structural similarity of $\mathbf{1}$ and $\mathbf{5}$ seems to argue against this hypothesis. Clearly, more work will be required to examine the ability of these functionalized sulfoximines to pass through the cell membrane, and the chemical pathways by which they might bebroken down within the cytosol. Compound $\mathbf{5}$ also causes cell death in ASNase-resistant MOLT-4 cells at concentrations higher than $250 \mu \mathrm{M}$, with this effect being augmented by depletion of exogenous L-asparagine. Although we cannot rule out the possibility that MOLT-4R cell death might arise from the interaction of $\mathbf{5}$ with other cellular targets (e.g. aminoacyl tRNA synthetases), when present in the medium at millimolar concentration, the results reported in this paper provide further evidence to support the idea that ASNS represents an intriguing, and druggable, target for the clinical treatment of acute lymphoblastic leukemia.

This conclusion would be greatly strengthened by siRNA experiments to knockdown hASNS concentrations, such as those reported for prostate cancer-derived cell lines. ${ }^{18}$ It is also possible that hASNS inhibitors might permit the use of lower levels of ASNase in current therapeutic protocols 
with a concomitant reduction in the side-effects associated with ASNase administration. ${ }^{3,58}$ Finally, recent findings showing the importance of hASNS for the growth of both androgenresponsive lymph node and prostate cancer cell lines and cells isolated from a castration-resistant (MDA PCa 180-30) prostate cancer xenograft suggest that analogs of sulfoximine $\mathbf{5}$ might represent lead compounds for identification of novel therapies against solid tumors, including those of the prostate. ${ }^{18}$ 


\section{Experimental}

\subsection{General}

All chemicals were obtained commercially and used without further purification unless otherwise stated. $\mathrm{N}, \mathrm{N}$-Dimethylformamide (DMF), 1,4-dioxane, acetonitrile $\left(\mathrm{CH}_{3} \mathrm{CN}\right), \mathrm{CH}_{2} \mathrm{Cl}_{2}$, tetrahydrofuran (THF) and triethylamine $\left(\mathrm{Et}_{3} \mathrm{~N}\right)$ were purchased from Wako Pure Chemical Industries (Osaka, Japan). These solvents were dried by distillation from $\mathrm{CaH}_{2}$, and stored over $4 \AA$ molecular sieves prior to use. Melting points (mp) were recorded using a Mettler FP62 melting point apparatus and are corrected. ${ }^{1} \mathrm{H}$ NMR and ${ }^{31} \mathrm{P}$ NMR spectra were recorded on a JEOL JNM-AL 300 (300 MHz for $\left.{ }^{1} \mathrm{H}\right) .{ }^{13} \mathrm{C}$ NMR spectra were recorded on a JEOL LAMBDA (100 MHz for ${ }^{13} \mathrm{C}$ ) under a complete ${ }^{1} \mathrm{H}$ decoupling condition. In $\mathrm{CDCl}_{3}, \mathrm{DMSO}-d_{6}$ and acetone- $d_{6},{ }^{1} \mathrm{H}\left(\delta_{\mathrm{H}}\right)$ and ${ }^{3} \mathrm{C}\left(\delta_{\mathrm{C}}\right)$ chemical shifts are reported downfield of tetramethylsilane as an internal reference $(\delta 0.0)$, except for measurements in $\mathrm{D}_{2} \mathrm{O}$ for which sodium 3-(trimethylsilyl)propanesulfonate was used as an internal standard $(\delta 0.0)$. Splitting patterns are abbreviated as follows: s, singlet; d, doublet; t, triplet, q; quartet; m, multiplet. ${ }^{31} \mathrm{P}$ chemical shifts $\left(\delta_{\mathrm{P}}\right)$ are reported downfield of $85 \% \mathrm{H}_{3} \mathrm{PO}_{4}$ as an external standard $\left(\delta_{P} 0.0\right)$. Infrared spectra were measured using a Horiba FT-720 Fourier Transform infrared spectrometer. Mass spectra were recorded on a high resolution JEOL JMS 700 spectrometer. Elemental analyses were performed using a Yanaco MT-5 apparatus. Reactions were monitored by analytical thin layer chromatography (TLC) on silica gel $60 \mathrm{~F}_{254}$ plates (Merck). Compounds were purified by column chromatography on $40-50 \mu \mathrm{m}$ silica gel $60 \mathrm{~N}$ (Kanto Kagaku), or by 
reverse-phase, medium pressure, column chromatography (Nihon Büchi) on either Diaion HP20SS resin (Mitsubishi Chemical Corporation) or a COSMOSIL 5C $\mathrm{C}_{18}$-PAQ column (Nacalai Tesque).

\subsubsection{2,2,2-Trichloroethyl $N$-2-(S-methylsulfanyl)ethylcarbamate (8)}

A solution of 2-sulfanylethylamine hydrochloride $(5.21 \mathrm{~g}, 45.9 \mathrm{mmol})$ and $\mathrm{NaOH}(5.5 \mathrm{~g}, 138$ $\mathrm{mmol})$ in $\mathrm{EtOH}(100 \mathrm{~mL})$ was stirred for $10 \mathrm{~min}$ at $0^{\circ} \mathrm{C}$. Methyl iodide $(6.84 \mathrm{~g}, 48.2 \mathrm{mmol})$ was then added dropwise to the mixture over a period of $30 \mathrm{~min}$ at $0^{\circ} \mathrm{C}$. After stirring for $3 \mathrm{~h}$ at ambient temperature, 2,2,2-trichloroethy chloroformate $(11.4 \mathrm{~g}, 53.8 \mathrm{mmol})$ was added dropwise at $0^{\circ} \mathrm{C}$. The mixture was stirred at ambient temperature overnight and filtered. The solvent was evaporated under reduced pressure, and the residual oil was purified by column chromatography on silica gel (EtOAc/hexane, 1:5 to 1:3) to afford the sulfide 8 as a colorless oil (11.3 g, 93\%): IR (NaCl, neat) $v_{\max } 3338,2950,2929,1731,1720,1525,1434,1403,1361,1322,1247,1197,1143,1083,1049$, $1033,958,902,815,767,721,651,568,476,449 \mathrm{~cm}^{-1} ;{ }^{1} \mathrm{H} \mathrm{NMR}\left(300 \mathrm{MHz}, \mathrm{CDCl}_{3}\right) \delta_{\mathrm{H}} 2.13(\mathrm{~s}, 3 \mathrm{H}$, $\left.\mathrm{SCH}_{3}\right), 2.68\left(\mathrm{t}, 2 \mathrm{H}, J=6.5 \mathrm{~Hz}, \mathrm{CH}_{2} \mathrm{~S}\right), 3.46\left(\mathrm{dt}, 2 \mathrm{H} J=6.3\right.$ and $\left.6.3 \mathrm{~Hz}, \mathrm{NHCH}_{2} \mathrm{CH}_{2} \mathrm{~S}\right), 4.74(\mathrm{~s}, 2 \mathrm{H}$, $\mathrm{Cl}_{3} \mathrm{CCH}_{2}$ ), 5.35 (br s, $\left.1 \mathrm{H}, \mathrm{NH}\right)$; HRMS (FAB, p-nitrobenzyl alcohol) calcd for $\mathrm{C}_{6} \mathrm{H}_{11} \mathrm{Cl}_{3} \mathrm{NO}_{2} \mathrm{~S}\left(\mathrm{MH}^{+}\right.$) 265.9576, found 265.9576 . 


\subsubsection{2,2,2-Trichloroethyl $N$-2-[S-methyl-(R,S)-sulfinyl]ethylcarbamate (9)}

The sulfide 8 (11.3 g, $42.4 \mathrm{mmol})$ was dissolved in aqueous tetrahydrofuran $\left(5: 2 \mathrm{THF}: \mathrm{H}_{2} \mathrm{O}, 70\right.$ $\mathrm{mL})$ and was cooled to $0^{\circ} \mathrm{C}$ before the addition of an aqueous solution $(30 \mathrm{~mL})$ of $\mathrm{NaIO}_{4}(11.8 \mathrm{~g}$, $55.2 \mathrm{mmol}$ ). The mixture was stirred overnight at ambient temperature and filtered. After the removal of THF under reduced pressure, EtOAc $(100 \mathrm{~mL})$ was added to the residue to extract the product. The EtOAc extracts were washed successively with water $(30 \mathrm{~mL})$ and sat. $\mathrm{NaCl}(30 \mathrm{~mL})$. After drying over $\mathrm{Na}_{2} \mathrm{SO}_{4}$ and filtration, evaporation gave the sulfoxide 9 as a pale yellow oil (10.9 $\mathrm{g}$, 90\% yield): IR ( $\mathrm{NaCl}$, neat) $v_{\max } 3400-3200$ (br), 2979, 2933, 2815, 1716, 1523, 1455, 1392, 1367, $1278,1251,1155,1049,1024,971,943,846,813,750,686,576,565,497,458,431 \mathrm{~cm}^{-1} ;{ }^{1} \mathrm{H}$ NMR $\left(300 \mathrm{MHz}, \mathrm{CDCl}_{3}\right) \delta_{\mathrm{H}} 2.67\left(\mathrm{~s}, 3 \mathrm{H}, \mathrm{SCH}_{3}\right), 2.82-2.90,3.03-3.12$ and 3.29-3.32 $\left(3 \times \mathrm{m}, 2 \mathrm{H}, \mathrm{CH}_{2} \mathrm{~S}\right)$, 3.74-3.78 (m, 2H, $\left.\mathrm{NHCH}_{2} \mathrm{CH}_{2} \mathrm{~S}\right), 4.73\left(\mathrm{~s}, 2 \mathrm{H}, \mathrm{Cl}_{3} \mathrm{CCH}_{2}\right), 6.00-6.11(2 \times$ br s, $1 \mathrm{H}, \mathrm{NH})$; HRMS (FAB, glycerol) calcd for $\mathrm{C}_{6} \mathrm{H}_{11} \mathrm{Cl}_{3} \mathrm{NO}_{3} \mathrm{~S}\left(\mathrm{MH}^{+}\right)$281.9525, found 281.9528 .

\subsubsection{2,2,2-Trichloroethyl $N$-2-[S-methyl-(R,S)-sulfonimidoyl]ethylcarbamate (10)}

To a solution of the sulfoxide $9(2.88 \mathrm{~g}, 10.2 \mathrm{mmol})$ in dry $\mathrm{CH}_{3} \mathrm{CN}$ was added $O$-mesitylsulfonylhydroxylamine (MSH) $)^{24,25}(3.29 \mathrm{~g}, 15.3 \mathrm{mmol})$ under an Ar atmosphere, and the mixture was stirred at ambient temperature for 4 days. The reaction mixture was evaporated, and the residual oil was dissolved in $\mathrm{CHCl}_{3} / \mathrm{MeOH}(10: 1,77 \mathrm{~mL})$. The resulting solution was washed successively with sat. $\mathrm{NaHCO}_{3}(30 \mathrm{~mL})$ and sat. $\mathrm{NaCl}(30 \mathrm{~mL})$. After drying over $\mathrm{Na}_{2} \mathrm{SO}_{4}$ and 
filtration, the filtrate was evaporated. The residual oil was purified by column chromatography on silica gel $\left(\mathrm{CHCl}_{3} / \mathrm{MeOH}, 19: 1\right.$ to $\left.10: 1\right)$ to afford sulfoximine $\mathbf{1 0}$ as a colorless oil (1.97 $\left.\mathrm{g}, 65 \%\right)$ : IR $\left(\mathrm{NaCl}\right.$, neat) $v_{\max } 3400-3200$ (br), 2979, 2933, 2815, 1716, 1523, 1455, 1392, 1367, 1278, 1251, 1155 , $1049,1024,971,943,846,813,750,686,576,565,497,458,431 \mathrm{~cm}^{-1} ;{ }^{1} \mathrm{H}$ NMR $\left(300 \mathrm{MHz}, \mathrm{CDCl}_{3}\right)$ $\delta_{\mathrm{H}} 3.07\left(\mathrm{~s}, 3 \mathrm{H}, \mathrm{SCH}_{3}\right), 3.29-3.41\left(\mathrm{~m}, 2 \mathrm{H}, \mathrm{CH}_{2} \mathrm{~S}\right), 3.79\left(\mathrm{dt}, 2 \mathrm{H}, J=6.0\right.$ and $\left.6.0 \mathrm{~Hz}, \mathrm{NHCH}_{2} \mathrm{CH}_{2} \mathrm{~S}\right)$, $4.73\left(\mathrm{~s}, 2 \mathrm{H}, \mathrm{Cl}_{3} \mathrm{CCH}_{2}\right.$ ), 6.15 (br t, $1 \mathrm{H}$, carbamate $\mathrm{NH}$ ), 8.5 (br s, 1H, S=NH); HRMS (FAB, p-nitrobenzyl alcohol) calcd for $\mathrm{C}_{6} \mathrm{H}_{12} \mathrm{Cl}_{3} \mathrm{~N}_{2} \mathrm{O}_{3} \mathrm{~S}\left(\mathrm{MH}^{+}\right)$296.9634, found 296.9634 .

\subsection{4. $\quad(R, S)$-Allyloxy $(N, N$-diisopropylamino $)(2$ ', 3 ' $-O$-isopropylideneadenosin-5'-yloxy $)$}

\section{phosphine (11)}

The phosphine 11 was synthesized in a yield of $63 \%$ after purification by silica gel column chromatography (acetone/hexane, 2:1 containing $5 \% \mathrm{Et}_{3} \mathrm{~N}$ ) according to the method as described previously $^{18}$ (Koizumi, M. et al. J. Am. Chem. Soc. 1999, 121, 5799-5800; Supporting information). The method for the preparation of allyloxy[bis(diisopropylamino)]phosphine is modified as follows:

$\mathrm{PCl}_{3}(7.87 \mathrm{~g}, 57.3 \mathrm{mmol})$ in anhydrous $\mathrm{CH}_{3} \mathrm{CN}(250 \mathrm{~mL})$ was cooled to $0^{\circ} \mathrm{C}$ before diisopropylamine (40.4 g, $400 \mathrm{mmol})$ in anhydrous $\mathrm{CH}_{3} \mathrm{CN}(10 \mathrm{~mL})$ was added over a 15 min period with vigorous stirring. The mixture was stirred at $0^{\circ} \mathrm{C}$ for $30 \mathrm{~min}$ and then at ambient temperature for $20 \mathrm{hr}$. The resulting reaction mixture was re-cooled to $-20^{\circ} \mathrm{C}$, and allyl alcohol $(3.33 \mathrm{~g}, 57.3 \mathrm{mmol})$ was added dropwise over $1 \mathrm{hr}$ with vigorous stirring. The mixture was stirred at ambient temperature 
for $19 \mathrm{hr}$, and the reaction mixture was filtered. The filtrate was evaporated, and the residual oil purified by distillation under reduced pressure (bp $90-95^{\circ} \mathrm{C}$ at $0.8 \mathrm{mmHg}$ ) to give allyloxy[bis(diisopropylamino)]phosphine as a colorless oil $(10.8 \mathrm{~g}, 65 \%):{ }^{1} \mathrm{H} \mathrm{NMR}(300 \mathrm{MHz}$, $\left.\mathrm{CDCl}_{3}\right) \delta_{\mathrm{H}} 1.17\left\{\mathrm{dd}, J=6.6\right.$ and $\left.4.5 \mathrm{~Hz}, 24 \mathrm{H}, \mathrm{N}\left[\mathrm{CH}\left(\mathrm{CH}_{3}\right)_{2}\right]_{2} \times 2\right\}, 3.54$ double septet, $J=10.8$ and $\left.6.6 \mathrm{~Hz}, 4 \mathrm{H}, \mathrm{N}\left[\mathrm{CH}\left(\mathrm{CH}_{3}\right)_{2}\right]_{2} \times 2\right\}, 4.08-4.13\left(\mathrm{~m}, 2 \mathrm{H}, \mathrm{OCH}_{2} \mathrm{CH}=\mathrm{CH}_{2}\right), 5.07-5.33\left(\mathrm{~m}, 2 \mathrm{H}, \mathrm{CH}=\mathrm{CH}_{2}\right)$, 5.89-6.03 (m, 1H, $\left.\mathrm{CH}=\mathrm{CH}_{2}\right) .{ }^{31} \mathrm{P}$ NMR $\left(121 \mathrm{MHz}, \mathrm{CDCl}_{3}\right) \delta_{\mathrm{P}} 122.4$.

\subsubsection{2,2,2-Trichloroethyl $2-\{N-[($ allyloxy $)(2,3$ ' $-O$-isopropylideneadenosin-5'-yloxy $)-(R, S)-$}

\section{phosphoryl]- $S$-methyl-( $R, S)$-sulfonimidoyl\}ethylcarbamate (12)}

The phosphine $11(2.40 \mathrm{~g}, 4.86 \mathrm{mmol})$ and the sulfoximine 10 (1.97 g, $6.62 \mathrm{mmol})$ were mixed in dry $\mathrm{CH}_{3} \mathrm{CN}(40 \mathrm{~mL})$ over $4 \AA$ molecular sieves $(0.5 \mathrm{~g})$ under an Ar atmosphere. Tetrazole $(0.461 \mathrm{~g}$, $6.62 \mathrm{mmol}$ ) was added, and the mixture stirred at ambient temperature under Ar for $2 \mathrm{~h}$ before the addition of tert-butyl hydroperoxide (1.41 g, $15.7 \mathrm{mmol})$. After stirring overnight, the reaction mixture was evaporated and the residue purified by column chromatography on silica gel $\left(\mathrm{CHCl}_{3} / \mathrm{MeOH}, 19: 1\right.$ to $\left.4: 1\right)$ to afford the $N$-adenylated sulfoximine $\mathbf{1 2}$ as a mixture of four diastereoisomers (2.68 g, 78\%, amorphous solid): IR ( $\mathrm{NaCl}$, neat) $v_{\max } 3400-3200$ (br), 2979, 2933, $2815,1716,1523,1455,1392,1367,1278,1251,1155,1049,1024,971,943,846,813,750,686$, 576, 565, 497, 458, $431 \mathrm{~cm}^{-1} ;{ }^{1} \mathrm{H}$ NMR $\left(300 \mathrm{MHz}, \mathrm{CDCl}_{3}\right) \delta_{\mathrm{H}} 1.40$ and $1.64(2 \times \mathrm{s}, 2 \times 3 \mathrm{H}$, isopropylidene), 3.23, 3.24, 3.28 and $3.30\left(4 \times \mathrm{s}, 3 \mathrm{H}, \mathrm{SCH}_{3}\right), 3.33-5.36$ (m, 17H, 5' $-\mathrm{CH}_{2}, 4^{\prime}$ '- $\mathrm{H}, 3^{\prime}-\mathrm{H}$, 
2'- $\mathrm{H}, \mathrm{NHCH}_{2} \mathrm{CH}_{2} \mathrm{~S}, \mathrm{CH}_{2} \mathrm{CH}=\mathrm{CH}_{2}, \mathrm{Cl}_{3} \mathrm{CCH}_{2}$, adenyl 6- $\mathrm{NH}_{2}$ ), 5.83-6.00 (m, 1H, $\mathrm{CH}=\mathrm{CH}_{2}$ ), 6.06-6.44 (m, 2H, 1'-H, NHCO), 8.29-8.49 (8 × s , 2H, adenyl 2-H and 8-H); ${ }^{13} \mathrm{C}$ NMR $(100 \mathrm{MHz}, \mathrm{CDCl} 3) \delta_{\mathrm{C}}$ 25.33 and $25.35 ; 27.14$ and $27.17 ; 35.22 ; 35.59,35.63$ and $35.69 ; 43.76,43.81,43.95$ and 44.00 ; 55.72 and $55.76 ; 66.17$ and $66.44 ; 67.47,67.53,67.57$ and $67.62 ; 74.55 ; 81.16$ and $81.25 ; 84.91$; $85.08,85.14,85.38$ and $85.52 ; 90.55,90.72,90.90$ and $91.16 ; 95.4 ; 114.37,114.40,114.42$ and 114.46 (adenine, C-5); 118.01, 118.06, 118.13 and 118.16 (C-8); 119.30, 119.40, 119.43 and 119.48 (C-4); 132.61 and 132.69 (C-2); 139.40, 139.43, 139.54 and 139.65 (C-6), 149.40 and 149.53; 153.23 and $153.27 ; 154.99,155.04,155.42$ and $155.48(\mathrm{C}=\mathrm{O})$ [two or four sets of peaks corresponding to four diastereoisomers were observed for each of a total of 22 carbons]; ${ }^{31} \mathrm{P}$ NMR $\left(121 \mathrm{MHz}, \mathrm{CDCl}_{3}\right) \delta_{\mathrm{p}} 2.58,2.85,3.36$ and 3.36. HRMS (FAB, p-nitrobenzyl alcohol) calcd for $\mathrm{C}_{22} \mathrm{H}_{32} \mathrm{Cl}_{3} \mathrm{~N}_{7} \mathrm{O}_{9} \mathrm{PS}\left(\mathrm{MH}^{+}\right)$706.0790, found 706.0776.

\subsubsection{Morpholine salt of 2,2,2-trichloroethyl $2-\{N$-[hydroxy (2',3'- $O$-isopropylideneadenosin-}

\section{5'-yloxy)phosphoryl]- $S$-methyl-( $R, S)$-sulfonimidoyl\}ethylcarbamate (13)}

The phosphoryl allyl ester 12 (1.05 g, $1.49 \mathrm{mmol})$ and morpholine (0.65 g, $7.43 \mathrm{mmol})$ were dissolved in dry THF $(10 \mathrm{~mL})$ under an Ar atmosphere. To this solution was added $\mathrm{Pd}\left(\mathrm{PPh}_{3}\right)_{4}(0.343$ $\mathrm{g}, 0.297 \mathrm{mmol}$ ) under an Ar atmosphere. The mixture was stirred at ambient temperature for $0.5 \mathrm{~h}$ and was evaporated to dryness. The residual oil was purified by reversed phase column chromatography on Diaion HP20SS eluting with a linear gradient of THF in $\mathrm{H}_{2} \mathrm{O}$ (0 to 99\%). The 
eluant was monitored with UV (254 nm), and the desired compound was eluted at 53:47 $\mathrm{H}_{2} \mathrm{O} / \mathrm{THF}$.

UV positive-fractions were combined and lyophilized to afford compound $\mathbf{1 3}$ as a mixture of two diastereomeric salts of morpholine (1.06 g, quant., pale yellow amorphous solid): ${ }^{1} \mathrm{H}$ NMR (300 MHz, DMSO- $\left.d_{6}\right) \delta_{\mathrm{H}} 1.32$ and $1.54(2 \times \mathrm{s}, 2 \times 3 \mathrm{H}$, isopropylidene $), 2.98\left(\mathrm{~m}, 4 \mathrm{H}\right.$, morpholine $\mathrm{NCH}_{2} \times$ 2), $3.08\left(\mathrm{~s}, 3 \mathrm{H}, \mathrm{SCH}_{3}\right), 3.1-3.6$ and 3.7-3.8 (m, 6H, $\mathrm{NHCH}_{2} \mathrm{CH}_{2} \mathrm{~S}, 5$ ' $\left.-\mathrm{CH}_{2}\right), 3.73(\mathrm{~m}, 4 \mathrm{H}$, morpholine $\left.\mathrm{OCH}_{2} \times 2\right), 4.37\left(\mathrm{~m}, 1 \mathrm{H}, 4^{\prime}-\mathrm{H}\right), 4.79\left(\mathrm{~s}, 2 \mathrm{H}, \mathrm{Cl}_{3} \mathrm{CH}_{2}\right), 5.06$ (br d, $\left.1 \mathrm{H}, J=6.3 \mathrm{~Hz}, 3^{\prime}-\mathrm{H}\right), 5.31$ (dd, 1H, $J=3.3$ and $\left.6.0 \mathrm{~Hz}, 2^{\prime}-\mathrm{H}\right), 6.14\left(\mathrm{~d}, J=3.3 \mathrm{~Hz}, 1 \mathrm{H}, 1^{\prime}-\mathrm{H}\right), 7.29$ (br s, 2H, adenyl 6- $\left.\mathrm{NH}_{2}\right), 8.16$ (s, 1H, adenyl 2-H), 8.3-8.4 (br m, 1H, CONH), 8.51 (s, 1H, adenyl 8-H); ${ }^{31} \mathrm{P}$ NMR (121 MHz, DMSO- $\left.d_{6}\right) \delta_{\mathrm{p}}$ 0.291 and 0.358. HRMS (FAB, glycerol) calcd for $\mathrm{C}_{19} \mathrm{H}_{28} \mathrm{Cl}_{3} \mathrm{~N}_{7} \mathrm{O}_{9} \mathrm{PS}\left(\mathrm{MH}^{+}\right)$666.0472, found 666.0487.

\subsubsection{2-Aminoethyl-[S-methyl-(R,S)-sulfonimidoyl]- $N$-adenylate (5)}

The $\mathrm{N}$-adenylated sulfoximine $13(0.99 \mathrm{~g}, 1.50 \mathrm{mmol})$ was suspended in TFA- $\mathrm{H}_{2} \mathrm{O}-\mathrm{CH}_{2} \mathrm{Cl}_{2}$ $(5: 1: 4,20 \mathrm{~mL})$ and was stirred at ambient temperature overnight to give a clear solution. The reaction mixture was evaporated to dryness to give a syrupy residue, which was then re-dissolved in AcOH $(20 \mathrm{~mL})$ before the addition of zinc powder $(1 \mathrm{~g}, 15.3 \mathrm{mmol})$. The mixture was stirred at ambient temperature overnight and was evaporated to dryness to give a residual syrup that was purified by reverse phase MPLC chromatography on Diaion HP20SS eluting with a linear gradient of THF in $\mathrm{H}_{2} \mathrm{O}$ (0 to 99\%). The eluant was monitored with UV (254 nm), and the desired compound was eluted 
at 99:1 $\mathrm{H}_{2} \mathrm{O}$ /THF. The UV positive-fractions were combined and lyophilized to afford the final product 5 as a mixture of two diastereoisomers (0.67 g, 90\%, colorless solid): ${ }^{1} \mathrm{H}$ NMR (300 MHz, DMSO- $\left.d_{6}\right) \delta_{\mathrm{H}} 3.31\left(\right.$ br s, 3H, $\mathrm{SCH}_{3}$ ), 3.61-4.11 (m, 7H, $\left.\mathrm{NH}_{2} \mathrm{CH}_{2} \mathrm{CH}_{2} \mathrm{~S}, 5^{\prime}-\mathrm{CH}_{2}, 4^{\prime}-\mathrm{H}\right), 4.19$ (dd, $1 \mathrm{H}, J$ $=3.6$ and $\left.4.5 \mathrm{~Hz}, 3^{\prime}-\mathrm{H}\right), 4.59\left(\mathrm{dd}, 1 \mathrm{H}, J=5.1\right.$ and $\left.5.1 \mathrm{~Hz}, 2^{\prime}-\mathrm{H}\right), 5.94\left(\mathrm{~d}, J=5.7 \mathrm{~Hz}, 1 \mathrm{H}, 1^{\prime}-\mathrm{H}\right), 7.60$ (br s, 2H, adenyl 6- $\left.\mathrm{NH}_{2}\right), 8.22$ and $8.31(2 \times \mathrm{s}, 1 \mathrm{H}$, adenyl $2-\mathrm{H}), 8.35$ and $8.40(2 \times \mathrm{s}, 1 \mathrm{H}$, adenyl 8-H); ${ }^{13} \mathrm{C}$ NMR (100 MHz, DMSO-d6) $\delta_{\mathrm{C}} 33.20\left(\mathrm{CH}_{2} \mathrm{NH}_{3}{ }^{+}\right), 42.86\left[\mathrm{~S}(=\mathrm{O})(=\mathrm{N})-\mathrm{CH}_{3}\right], 50.59$ $\left[\mathrm{CH}_{2} \mathrm{~S}(=\mathrm{O})(=\mathrm{N})\right], 63.39$ (ribose, C-5'), $70.55\left(\mathrm{C}-3^{\prime}\right), 73.79\left(\mathrm{C}-2^{\prime}\right), 83.38\left(\mathrm{C}-4^{\prime}\right), 87.38\left(\mathrm{C}^{\prime} 1^{\prime}\right), 118.31$ (adenine, C-5), 140.46 (C-8), 149.23 (C-4), 152.79 (C-2), 154.17 (C-6); ${ }^{31} \mathrm{P}$ NMR (121 MHz, DMSO- $\left.d_{6}\right) \delta_{\mathrm{p}}$ 1.45. HRMS (FAB, glycerol) calcd for $\mathrm{C}_{13} \mathrm{H}_{23} \mathrm{~N}_{7} \mathrm{O}_{7} \mathrm{PS}\left(\mathrm{MH}^{+}\right)$452.1117, found 452.1115 .

\subsubsection{Allyl 3-(S-methylsulfanyl)propanoate (14)}

Allyl bromide (7.02 g, $58.0 \mathrm{mmol})$ was added dropwise under an Ar atmosphere to an ice-cooled, vigorously stirred suspension of 3-methylsulfanylpropanoic acid (5.80 g, $48.3 \mathrm{mmol}), \mathrm{K}_{2} \mathrm{CO}_{3}(7.34 \mathrm{~g}$, $53.1 \mathrm{mmol})$ in dry acetone $(40 \mathrm{~mL})$. After completion of the addition of allyl bromide, the mixture was heated under reflux for $14 \mathrm{~h}$. The reaction mixture was filtered and evaporated to give a residual yellow oil. $\mathrm{CHCl}_{3}(80 \mathrm{~mL})$ was added to the residue and washed successively with water $(30 \mathrm{~mL})$ and sat. $\mathrm{NaCl}(30 \mathrm{~mL})$. The water layer was extracted with $\mathrm{CHCl}_{3}(50 \mathrm{~mL} \times 2)$, and the combined organic layers were dried over $\mathrm{Na}_{2} \mathrm{SO}_{4}$ and filtered. The filtrate was evaporated to give the allyl ester 
14 as a pale yellow oil (4.25 g, 55\%): ${ }^{1} \mathrm{H} \mathrm{NMR}\left(300 \mathrm{MHz}, \mathrm{CDCl}_{3}\right) \delta_{\mathrm{H}} 2.13\left(\mathrm{~s}, 3 \mathrm{H}, \mathrm{SCH}_{3}\right), 2.66(\mathrm{t}, 2 \mathrm{H}$, $\left.J=6.8 \mathrm{~Hz}, \mathrm{CH}_{2} \mathrm{~S}\right), 2.76\left(\mathrm{t}, 2 \mathrm{H}, J=6.8 \mathrm{~Hz}, \mathrm{CH}_{2} \mathrm{CO}\right), 4.56-4.66\left(\mathrm{~m}, 2 \mathrm{H}, \mathrm{OCH}_{2} \mathrm{CH} \mathrm{CH}_{2}\right), 5.24(\mathrm{dq}, 1 \mathrm{H}$, $J=10.5$ and $\left.1.2 \mathrm{~Hz}, \mathrm{CH}_{2} \mathrm{CH}=\mathrm{CHH}\right), 5.33\left(\mathrm{dq}, 1 \mathrm{H}, J=17.4\right.$ and $\left.1.5 \mathrm{~Hz}, \mathrm{CH}_{2} \mathrm{CH}=\mathrm{CH} H\right), 5.92$ (ddt, $1 \mathrm{H}, J=17.3,10.4$ and $\left.6.0 \mathrm{~Hz}, \mathrm{CH}_{2} \mathrm{CH}=\mathrm{CH}_{2}\right)$; HRMS (FAB, glycerol) calcd for $\mathrm{C}_{7} \mathrm{H}_{13} \mathrm{O}_{2} \mathrm{~S}\left(\mathrm{MH}^{+}\right)$ 161.0637, found 161.0637 .

\subsubsection{Allyl 3-[S-methyl-(R,S)-sulfinyl]propanoate (15)}

The sulfide $14(4.25 \mathrm{~g}, 26.5 \mathrm{mmol})$ was dissolved in $\mathrm{THF}-\mathrm{H}_{2} \mathrm{O}(5: 1,60 \mathrm{~mL})$ and was cooled at $0^{\circ} \mathrm{C}$ before the addition of an aqueous solution $(10 \mathrm{~mL})$ of $\mathrm{NaIO}_{4}(7.38 \mathrm{~g}, 34.5 \mathrm{mmol})$. The mixture was stirred at ambient temperature overnight and was filtered. After removal of THF under reduced pressure, $\mathrm{CHCl}_{3}(80 \mathrm{~mL})$ was added to the residual aqueous mixture, and the organic layer was washed successively with water $(30 \mathrm{~mL})$ and sat. $\mathrm{NaCl}(30 \mathrm{~mL})$. The water layer was extracted with $\mathrm{CHCl}_{3}(50 \mathrm{~mL} \times 2)$, and the combined organic layers were dried over $\mathrm{Na}_{2} \mathrm{SO}_{4}$ and filtered. The filtrate was evaporated to give the racemic sulfoxide 15 as an yellow oil (4.13 $\mathrm{g}, 88 \%)$ : IR ( $\mathrm{NaCl}$, neat) $v_{\max }, 2983,2925,2892,1785,1648,1419,1378,1348,1240,1186,1145,1031$ (S=O), 991, 948, 777, 696, 559, $507 \mathrm{~cm}^{-1} ;{ }^{1} \mathrm{H}$ NMR $\left(300 \mathrm{MHz}, \mathrm{CDCl}_{3}\right) \delta_{\mathrm{H}} 2.61\left(\mathrm{~s}, 3 \mathrm{H}, \mathrm{SCH}_{3}\right), 2.80-3.13(\mathrm{~m}, 4 \mathrm{H}$, $\left.\mathrm{CH}_{2} \mathrm{CH}_{2} \mathrm{~S}\right), 4.59-4.72\left(\mathrm{~m}, 2 \mathrm{H}, \mathrm{OCH}_{2} \mathrm{CH}=\mathrm{CH}_{2}\right), 5.22-5.40\left(\mathrm{~m}, 2 \mathrm{H}, \mathrm{CH}=\mathrm{CH}_{2}\right), 5.86-5.98(\mathrm{~m}, 1 \mathrm{H}$, $\left.\mathrm{CH}=\mathrm{CH}_{2}\right)$; HRMS (FAB, glycerol) calcd for $\mathrm{C}_{7} \mathrm{H}_{13} \mathrm{O}_{3} \mathrm{~S}\left(\mathrm{MH}^{+}\right)$177.0586, found 177.0589. 


\subsubsection{Allyl 3-[S-methyl-(R,S)-sulfonimidoyl]propanoate (16)}

To a solution of the sulfoxide $15(1.40 \mathrm{~g}, 7.94 \mathrm{mmol})$ in dry $\mathrm{CH}_{3} \mathrm{CN}$ (20 mL) was added MSH (2.56 g, $11.9 \mathrm{mmmol})$ under an Ar atmosphere. The mixture was stirred at ambient temperature for 4 days until completion of the reaction. The reaction mixture was evaporated, and the residual oil was dissolved in EtOAc $(50 \mathrm{~mL})$. The solution was washed successively with sat. $\mathrm{NaHCO}_{3}(30 \mathrm{~mL})$ and sat. $\mathrm{NaCl}(30 \mathrm{~mL})$. After drying over $\mathrm{Na}_{2} \mathrm{SO}_{4}$ and filtration, the filtrate was evaporated. The residual oil was purified by column chromatography on silica gel $\left(\mathrm{CHCl}_{3} / \mathrm{MeOH}, 19: 1\right.$ to $\left.10: 1\right)$ to afford sulfoximine 16 as a pale brown oil (1.28 g, 84\%): IR ( $\mathrm{NaCl}$, neat) $v_{\max } 3606-3093$ (br), 1731, 1646, 1606, 1565, 1490, 1452, 1417, 1378, 1338, 1241, $1201(\mathrm{O}=\mathrm{S}=\mathrm{N}), 1087,1024(\mathrm{~S}=\mathrm{O}), 989,933,842$, 788, 748, 680, 582, 518, 468, 431, $410 \mathrm{~cm}^{-1} ;{ }^{1} \mathrm{H}$ NMR (300 MHz, $\left.\mathrm{CDCl}_{3}\right) \delta_{\mathrm{H}} 2.60$ (br s, $\left.1 \mathrm{H}, \mathrm{NH}\right)$, $2.93\left(\mathrm{t}, 2 \mathrm{H}, J=7.4 \mathrm{~Hz}, \mathrm{CH}_{2} \mathrm{CH}_{2} \mathrm{~S}\right), 3.02\left(\mathrm{~s}, 3 \mathrm{H}, \mathrm{SCH}_{3}\right), 3.46\left(\mathrm{t}, 2 \mathrm{H}, J=7.2 \mathrm{~Hz}, \mathrm{CH}_{2} \mathrm{CH}_{2} \mathrm{~S}\right), 4.64(\mathrm{dt}$, $2 \mathrm{H}, J=6.0$ and $\left.1.2 \mathrm{~Hz}, \mathrm{OCH}_{2} \mathrm{CH}=\mathrm{CH}_{2}\right), 5.27(\mathrm{dq}, 1 \mathrm{H}, J=10.5$ and $1.2 \mathrm{~Hz}, \mathrm{CH}=\mathrm{CH} H), 5.34(\mathrm{dq}, 1 \mathrm{H}$, $J=15.0$ and $1.5 \mathrm{~Hz}, \mathrm{CH}=\mathrm{CHH}), 5.92\left(\mathrm{ddt}, 1 \mathrm{H}, J=15.0,10.5\right.$ and $6.0 \mathrm{~Hz}, \mathrm{CH}_{2} \mathrm{CH}=\mathrm{CH}_{2}$ ); $\mathrm{HRMS}$ (FAB, glycerol) calcd for $\mathrm{C}_{7} \mathrm{H}_{14} \mathrm{NO}_{3} \mathrm{~S}\left(\mathrm{MH}^{+}\right)$192.0691, found 192.0691 .

\subsubsection{Allyl 3- $\{N-[($ allyloxy $)(2$ ', 3'- $O$-isopropylideneadenosin-5'-yloxy)-(R, $S)-$ phosphoryl]- $S$-methyl-(R, $S$ )-sulfonimidoyl\}propanoate (17)}

The reactive phosphine $11(1.68 \mathrm{~g}, 3.40 \mathrm{mmol})$ and the sulfoximine $16(0.94 \mathrm{~g}, 4.92 \mathrm{mmol})$ and $4 \AA$ molecular sieves $(1.0 \mathrm{~g})$ were mixed in dry $\mathrm{CH}_{3} \mathrm{CN}(30 \mathrm{~mL})$ under an $\mathrm{Ar}$ atmosphere. 
Tetrazole $(0.344 \mathrm{~g}, 4.92 \mathrm{mmol})$ was added, and the resulting mixture was stirred at ambient temperature under an Ar atmosphere for $2 \mathrm{~h}$ before the addition of tert-butyl hydroperoxide $(0.972 \mathrm{~g}$, $7.55 \mathrm{mmol}$ ). After overnight stirring, the reaction mixture was evaporated, and the residue purified by column chromatography on silica gel $\left(\mathrm{CHCl}_{3} / \mathrm{MeOH}, 19: 1\right.$ to $\left.4: 1\right)$ to afford sulfoximine 17 as a mixture of four diastereoisomers $\left(1.54 \mathrm{~g}, 76 \%\right.$, amorphous solid): IR ( $\mathrm{NaCl}$, neat) $v_{\max } 3586-3264$ (br), 2989, 2938, 1735, 1644, 1600, 1506, 1475, 1423, 1376, 1330, 129, 1245, 1214 (O=S=N), 1157 , 1076, $1016(\mathrm{~S}=\mathrm{O}), 993,927,863,786,728,680,649,580,549,511,460,449,403 \mathrm{~cm}^{-1} ;{ }^{1} \mathrm{H}$ NMR $\left(300 \mathrm{MHz}, \mathrm{CDCl}_{3}\right) \delta_{\mathrm{H}} 1.39$ and $1.63(2 \times \mathrm{s}, 2 \times 3 \mathrm{H}$, isopropylidene $), 2.93-3.01\left(\mathrm{~m}, 2 \mathrm{H}, \mathrm{CH}_{2} \mathrm{CH}_{2} \mathrm{~S}\right)$, $3.19,3.22,3.27\left(3 \times \mathrm{s}, 3 \mathrm{H}, \mathrm{SCH}_{3}\right), 3.49-3.80\left(\mathrm{~m}, 2 \mathrm{H}, 5^{\prime}-\mathrm{CH}_{2}\right), 4.09-4.30\left(\mathrm{~m}, 2 \mathrm{H}, \mathrm{CH}_{2} \mathrm{CH}_{2} \mathrm{~S}\right)$, 4.38-4.63 (m, 6H, $\mathrm{COOCH}_{2} \mathrm{CH}=\mathrm{CH}_{2}, \quad \mathrm{POCH}_{2} \mathrm{CH}=\mathrm{CH}_{2}, \quad 4^{\prime}-\mathrm{H}, \quad 3$ '- $\left.\mathrm{H}\right), \quad 5.08-5.40 \quad(\mathrm{~m}, \quad 5 \mathrm{H}$, $\mathrm{COOCH}_{2} \mathrm{CH}=\mathrm{CH}_{2}, \mathrm{POCH}_{2} \mathrm{CH}=\mathrm{CH}_{2}, 2$ '-H), 5.80-5.97 (m, 2H, $\left.\mathrm{COOCH}_{2} \mathrm{CH}=\mathrm{CH}_{2}, \mathrm{POCH}_{2} \mathrm{CH}_{=} \mathrm{CH}_{2}\right)$, 6.14 (br s, $2 \mathrm{H}, \mathrm{NH}_{2}$ ), 6.22 (br s, $\left.1 \mathrm{H}, 1^{\prime}-\mathrm{H}\right), 8.19$ (s, 1H, adenyl 2-H), 8.36 (s, 1H, adenyl 8-H); ${ }^{31} \mathrm{P}$ NMR $\left(121 \mathrm{MHz}, \mathrm{CDCl}_{3}\right) \delta_{\mathrm{p}} 2.44,2.60,2.66,3.52$. HRMS (FAB, p-nitrobenzyl alcohol) calcd for $\mathrm{C}_{23} \mathrm{H}_{34} \mathrm{~N}_{6} \mathrm{O}_{9} \mathrm{PS}\left(\mathrm{MH}^{+}\right)$601.1848, found 601.1844.

\subsubsection{Bis-morpholine salt of $3-\left\{N-\left[\left(2^{\prime}, 3\right.\right.\right.$ ' $-O$-Isopropylideneadenosin-5'-yloxy $)$ phosphoryl $]-S$ -}

\section{methyl-( $R, S)$-sulfonimidoyl\}propanoic acid (18)}

The allyl ester $17(1.53 \mathrm{~g}, 2.55 \mathrm{mmol})$ and morpholine $(2.21 \mathrm{~g}, 25.5 \mathrm{mmol})$ were dissolved in dry THF (20 mL) under an Ar atmosphere. To this solution was added $\mathrm{Pd}\left(\mathrm{PPh}_{3}\right)_{4}(0.59 \mathrm{~g}, 0.51 \mathrm{mmol})$ 
under an Ar atmosphere. The mixture was stirred at ambient temperature for overnight. The reaction mixture was evaporated to dryness. The residue oil was purified by reversed phase, medium-pressure column chromatography on ODS eluting with a linear gradient of $\mathrm{MeOH}$ in $\mathrm{H}_{2} \mathrm{O}(0$ to $100 \%)$. The eluant was monitored with UV (254 nm), and the desired product 18 eluted at 30:70 $\mathrm{H}_{2} \mathrm{O} / \mathrm{MeOH}$. UV positive-fractions were then combined and lyophilized to afford $\mathbf{1 8}$ as a mixture of two diastereomers (1.33 g, quant, yellow oil): ${ }^{1} \mathrm{H}$ NMR (300 MHz, DMSO- $\left.d_{6}\right) \delta_{\mathrm{H}} 1.33$ and $1.54(2 \times \mathrm{s}, 2 \times 3 \mathrm{H}$, isopropylidene), $2.92\left(\mathrm{~d}, 2 \mathrm{H}, J=6.6 \mathrm{~Hz}, \mathrm{CH}_{2} \mathrm{CH}_{2} \mathrm{~S}\right), 3.03\left(\mathrm{br} \mathrm{s}, 3 \mathrm{H}, \mathrm{SCH}_{3}\right), 3.41-3.82(\mathrm{~m}, 4 \mathrm{H}$, $\left.\mathrm{CH}_{2} \mathrm{CH}_{2} \mathrm{~S}, 5^{\prime}-\mathrm{CH}_{2}\right), 4.37$ (m, 1H, 4'-H), 5.00-5.17 (m, 1H, J = 6.3, 3'-H), 5.32 (m, 1H, 2'-H), 6.14 (br d, $\left.J=3.0 \mathrm{~Hz}, 1 \mathrm{H}, 1^{\prime}-\mathrm{H}\right), 7.29$ (br s, 2H, $\mathrm{NH}_{2}$ ), 8.16 (s, 1H, adenyl 2-H), 8.49 (s, 1H, adenyl 8-H); ${ }^{31} \mathrm{P}$ NMR (121 MHz, DMSO- $d_{6}$ ) $\delta_{\mathrm{p}}$ 0.02, 5.59. HRMS (FAB, glycerol) calcd for $\mathrm{C}_{17} \mathrm{H}_{26} \mathrm{~N}_{6} \mathrm{O}_{9} \mathrm{PS}$ $\left(\mathrm{MH}^{+}\right)$521.1222, found 521.1227.

\subsubsection{3- $\{N-[($ Adenosin-5'-yloxy $)($ hydroxy)phosphoryl]-(R,S)-S-methylsulfonimidoyl $\}$}

\section{propanoic acid (6)}

A suspension of compound $\mathbf{1 8}(1.34 \mathrm{~g}, 2.57 \mathrm{mmol})$ in 5:1:4 TFA- $\mathrm{H}_{2} \mathrm{O}-\mathrm{CH}_{2} \mathrm{Cl}_{2}(30 \mathrm{~mL})$ was stirred at ambient temperature overnight to give a clear solution. The reaction mixture was evaporated to dryness to give a residual syrup that was purified by reversed phase, medium-pressure column chromatography on ODS eluting with a linear gradient of $\mathrm{MeOH}$ in $\mathrm{H}_{2} \mathrm{O}$ (0 to $\left.100 \%\right)$. The eluant was monitored with UV (254 nm), and the desired sulfoximine 6 eluted at 60:40 $\mathrm{H}_{2} \mathrm{O} / \mathrm{MeOH}$. 
UV positive-fractions were combined and triturated in EtOAc $(10 \mathrm{~mL})$. The suspension was filtrated, and the precipitate was washed with EtOAc $(20 \mathrm{~mL})$ to afford the final product as a mixture of two diastereomers 6 (1.23 g, quant, colorless solid): ${ }^{1} \mathrm{H}$ NMR $\left(300 \mathrm{MHz}, \mathrm{DMSO}-d_{6}\right) \delta_{\mathrm{H}} 2.73-2.80(\mathrm{~m}, 2 \mathrm{H}$, $\left.\mathrm{CH}_{2} \mathrm{CH}_{2} \mathrm{~S}\right), 3.00-4.07$ (m, 7H, 5'- $\left.\mathrm{CH}_{2}, \mathrm{SCH}_{3}, \mathrm{CH}_{2} \mathrm{CH}_{2} \mathrm{~S}\right), 4.18\left(\mathrm{~m}, 1 \mathrm{H}, 4^{\prime}-\mathrm{H}\right), 4.55-4.66$ (m, 1H, 3'-H) , $5.52\left(\mathrm{~m}, 2 \mathrm{H}, 2^{\prime}-\mathrm{H}\right), 5.92\left(\mathrm{~d}, J=5.7 \mathrm{~Hz}, 1 \mathrm{H}, 1^{\prime}-\mathrm{H}\right), 7.27$ (br s, 2H, $\left.\mathrm{NH}_{2}\right), 8.15$ (s, 1H, adenyl 2-H), $8.34\left(\mathrm{~s}, 1 \mathrm{H}\right.$, adenyl 8-H); ${ }^{13} \mathrm{C}$ NMR $\left(100 \mathrm{MHz}, \mathrm{DMSO}-d_{6}\right) \delta_{\mathrm{C}} 27.62\left(\mathbf{C H}_{2} \mathrm{COOH}\right), 41.64$ and $42.85\left[\mathrm{~S}(=\mathrm{O})(=\mathrm{N})-\mathrm{CH}_{3}\right], 51.15$ and $51.19\left[\mathrm{CH}_{2} \mathrm{~S}(=\mathrm{O})(=\mathrm{N})\right], 63.34$ (ribose, $\left.\mathrm{C}-5^{\prime}\right), 70.58\left(\mathrm{C}-3^{\prime}\right), 73.53$ (C-2’), 83.27 (C-4'), 87.04 (C-1'), 118.93 (adenine, C-5), 139.50 (C-8), 149.56 (C-4), 152.27 (C-2), $155.71(\mathrm{C}-6), 171.68(\mathrm{C}=\mathrm{O}) ;{ }^{31} \mathrm{P}$ NMR $\left(121 \mathrm{MHz}, \mathrm{DMSO}-d_{6}\right) \delta_{\mathrm{p}} 1.903$. HRMS (FAB, glycerol) calcd for $\mathrm{C}_{14} \mathrm{H}_{22} \mathrm{~N}_{6} \mathrm{O}_{9} \mathrm{PS}\left(\mathrm{MH}^{+}\right)$481.0907, found 481.0907.

\subsection{Steady-state kinetic assays}

Unless otherwise stated, all chemicals and reagents were purchased from Sigma Aldrich and were of the highest purity available. Protein concentrations were determined using the Bradford assay (Pierce) ${ }^{59}$ and L-glutamine was recrystallized prior to use in all kinetic assays. ${ }^{37}$ The inhibition of human ASNS by $\mathbf{5}$ and $\mathbf{6}$ was measured by determining their effect on PPi production under steady-state conditions, using a continuous assay in which PPi formation is enzyme-coupled to NADH consumption $(340 \mathrm{~nm})$ (pyrophosphate reagent, Sigma technical bulletin BI-100). Assay mixtures in which $25 \mathrm{mM} \mathrm{L-glutamine} \mathrm{was} \mathrm{used} \mathrm{as} \mathrm{the} \mathrm{nitrogen} \mathrm{source} \mathrm{contained} \mathrm{sulfoximine} \mathbf{5}$ at 
various fixed concentrations $(0,0.2,0.5,1,2$ and $5 \mu \mathrm{M})$ and $0.5 \mathrm{mM} \mathrm{ATP}, 10 \mathrm{mM}$ L-Asp, and the pyrophosphate reagent $(350 \mu \mathrm{L})$ in $100 \mathrm{mM}$ EPPS buffer, $\mathrm{pH} 8.0$, containing $10 \mathrm{mM} \mathrm{MgCl}{ }_{2}(1 \mathrm{~mL}$ total volume). Reactions were initiated by the addition of hASNS (4 $\mu \mathrm{g})$, and pyrophosphate production was monitored spectrophotometrically at $25^{\circ} \mathrm{C}$ over a period of $20 \mathrm{~min}$. When $100 \mathrm{mM}$ $\mathrm{NH}_{4} \mathrm{Cl}$ was the nitrogen source, reaction mixtures were identical to those outlined above except for the fixed concentrations of sulfoximine $\mathbf{5}(0,0.4,0.7,1,2.5,5$ and $10 \mu \mathrm{M})$. Each data point represents the average of duplicate experiments. Identical procedures were employed to characterize the interaction of sulfoximine $\mathbf{6}$ with hASNS except for the fixed concentrations of $\mathbf{6}$, which were 0 , 5, 25, 40, 60 and $80 \mu \mathrm{M}$, and $0,2,5,8,15$ and $20 \mu \mathrm{M}$ for the glutamine- and ammonia-dependent synthetase reactions, respectively. Control experiments using known amounts of $\mathrm{PP}_{\mathrm{i}}$ demonstrated that the assay pyrophosphate reagent was not affected by the presence of either sulfoximine $\mathbf{5}$ or $\mathbf{6}$.

The four sets of progress curves (Figures 2 and 3) were analyzed by fitting the data to the following equation, using the Kaleidagraph v3.5 software package (Synergy): ${ }^{35}$

$$
\left[P P_{i}\right]=v_{s s} t+\frac{\left(v_{0}-v_{s s}\right)}{k}\left(1-e^{-k t}\right)
$$

where $\left[\mathrm{PP}_{\mathrm{i}}\right]$ is the concentration of inorganic pyrophosphate formed at time $t, v_{o}$ and $v_{s s}$ are the initial and steady-state rates, respectively, and $k$ is the apparent first-order rate constant for isomerization of EI to EI*. By analogy to the known kinetic behavior of the adenylated sulfoximine 1, it was assumed that the inhibitors $\mathbf{5}$ and $\mathbf{6}$ bound to the free enzyme being competitive with respect to ATP, as shown in the following kinetic model: 


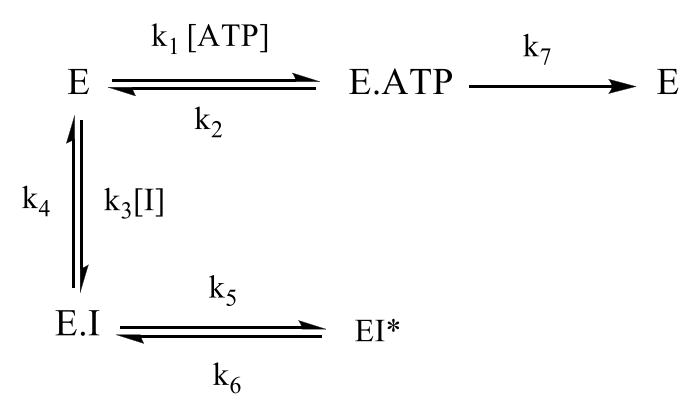

Having values for $k, v_{o}$ and $v_{s s}$ in hand at each concentration of the inhibitors, this information was then used to calculate an estimate of $k_{6}$, using equation (2):

$$
k_{6}=k \frac{v_{s s}}{v_{o}}
$$

With an estimate of $k_{6}$, values of $K_{i}$ and $k_{5}$ were determined by fitting the variation of $k$ with [I] using equation (3):

$$
k=k_{6}+k_{5}\left[\frac{I / K_{i}}{\left(1+[A T P] / K_{a}+I / K_{i}\right)}\right]
$$

where $I$ is the concentration of the inhibitor, $K_{\mathrm{i}}$ is the initial inhibition constant, $K_{a}$ is taken to be 0.1 $\mathrm{mM},{ }^{38}$ and $[A T P]=0.5 \mathrm{mM}$. Plots showing the variation in $k$ with sulfoximine concentration for the four sets of progress curves (Figures 2 and 3) are provided in supporting information. 
The overall inhibition constant $K_{i}^{*}$ was computed using equation (4):

$$
K_{i}^{*}=\frac{K_{i} k_{6}}{k_{5}+k_{6}}
$$

\subsection{Cell-based assays}

MOLT4R and MOLT4S cell cultures were maintained with RPMI 1640 medium (Hyclone), supplemented with heat-inactivated 10\% FBS (Hyclone) and $100 \mathrm{U} / \mathrm{mL}$ penicillin-streptomycin (Mediatech Inc). The suspension cultures were incubated in $95 \%$ air with $5 \% \mathrm{CO}_{2}$ at $37^{\circ} \mathrm{C}$. Twenty-four hours before all experiments, cells were collected by centrifugation for 3 min at $250 \mathrm{~g}$, rinsed twice with phosphate buffered saline $(0.15 \mathrm{M} \mathrm{NaCl}, 10 \mathrm{mM}$ sodium phosphate, $\mathrm{pH} 7.4)$ and re-suspended in fresh medium before being seeded into 96-well plates at an initial density of 50,000 cells/well. The cells were incubated with sulfoximine 5 at concentrations varying from 10-1000 $\mu \mathrm{M}$ in the presence or absence of $1 \mathrm{U} / \mathrm{mL}$ of ASNase (Worthington Biochemical). After $48 \mathrm{~h}$, the viability of the cells was determined using 3-(4,5-dimethylthiazol-2-yl)-5-(3-carboxymethoxyphenyl)-2-(4sulfophenyl)-2H-tetrazolium (MTS) cell proliferation assay (Promega). The optical density was read at $490 \mathrm{~nm}$ by a VERSAmax Microplate Reader (Molecular Diagnostics). The mean cell titer of treated samples relative to control cells prior to treatment (time $=0)$ was calculated, and the data expressed as the mean $\pm \mathrm{SD}$ of triplicate experiments. 


\subsection{Molecular modeling}

All four qualitative models of the sulfoximine/AS-B complexes were built from an initial model of the AS-B/L-glutamine/ $\beta$-aspartyl-AMP $/ \mathrm{MgPP}_{\mathrm{i}}$, which we have described previously. ${ }^{20}$ Each sulfoximine was superimposed onto bound $\beta$-aspartyl-AMP. The $\mathrm{PP}_{\mathrm{i}}$ moiety bound to the $\mathrm{Mg}(\mathrm{II})$ ion and the $\beta$-aspartyl-AMP intermediate were then deleted, and the vacant coordination sites on the metal ion filled with water molecules. These operations were performed using the Maestro v9.0 software package (Schrödinger LLC). Missing hydrogen atoms were added to the resulting model structure using the HBUILD algorithm, ${ }^{60}$ which was then solvated in an octahedral box of TIP3P $\mathrm{P}^{40}$ water molecules after the addition of ions to give a system of zero net charge. The final model was then obtained by energy minimization using the steepest descents and ABNR algorithms implemented in the CHARMM software package. ${ }^{61}$ These calculations employed the CHARMM27 force field ${ }^{41}$ with missing parameters for the sulfoximine ligand being obtained from the CGenFF software package. ${ }^{42}$ Electrostatic interactions were computed using the particle mesh Ewald algorithm (12 $\AA$ cutoff $)^{62}$ and a force-switching function was employed for Lennard-Jones interactions in the range of 10-12 A. Coordinates for each of the model complexes are available from the authors by request.

The electrostatic potential of the synthetase active site was calculated by solving the Poisson-Boltzmann equation ${ }^{45}$ using the APBS interface, ${ }^{46,47}$ with atomic charge and radius parameters being assigned from the CHARMM force field in the PDB2PQR web interface. ${ }^{63,64}$ 


\section{Acknowledgments}

This work was supported, in part, by a Grant-in-Aid for Scientific Research (C) from Japan Society for the Promotion of Science (contract No. 23510278) and by a Grant-in-Aid for the Global COE Program, "International Center for Integrated Research and Advanced Education in Materials Science," from the Ministry of Education, Culture, Sports, Science and Technology of Japan (J.H). These studies were initiated through the provision of a grant from the Chiles Endowment Biomedical research program of the Florida Department of Health (N.G.J.R.) and we thank the University of Florida for additional studentship support (Y.A. and L.H.). Molecular graphics and analyses were performed with the UCSF Chimera package. Chimera is developed by the Resource for Biocomputing, Visualization, and Informatics at the University of California, San Francisco, with support from the National Institutes of Health (National Center for Research Resources grant 2P41RR001081, National Institute of General Medical Sciences grant 9P41GM103311).

\section{Supplementary data}

Supplementary data associated with this article can be found, in the online version, at http://dx.doi.org/10.1016/j.bmc.2012.07.047. 


\section{References and notes}

1. Pui, C.-H.; Relling, M. V.; Downing, J. R. New Engl.J. Med. 2004, 350, 1535-1548.

2. Muller, H. J.; Boos, J. Crit. Rev. Oncol. Hematol. 1998, 28, 97-113.

3. Pieters, R.; Hunger, S. P.; Boos, J.; Rizzari, C.; Silverman, L.; Baruchel, A.; Goekbuget, N.; Schrappe, M.; Pui, C. H.; Cancer 2011, 117, 238-249.

4. Aghaiypour, K.; Wlodawer, A.; Lubowski, J. Biochemistry 2001, 40, 5655-5664.

5. Kravchenko, O. V.; Kislitsin, Y. A.; Popov, A. N.; Nikonov, S. V.; Kuranova, I. P. Acta Crystallogr. Sect. D 2009, 64, 248-256.

6. Syrigou, E.; Makrilia, N.; Koti, I.; Saif, M. W.; Syrigos, K. N. Anti-Cancer Drugs 2009, 20, $1-6$.

7. Asselin, B. L. Adv. Exp. Med. Biol. 1999, 457, 621-629.

8. Pui, C. H.; Campana, D.; Pei, D.; New Engl. J. Med. 2009, 360, 2730-2741.

9. Richards, N. G. J.; Kilberg, M. S. Annu. Rev. Biochem. 2006, 75, 629-654.

10. Chakrabarti, R.; Schuster, S. M. J. Ped.Haematol. Oncol. 1997, 4, 597-611.

11. Kiryama, Y.; Kubota, M.; Takimoto, T.; Kitoh, T.; Tanizawa, A.; Akiyama, Y.; Mikawa, H. Leukemia 1989, 3, 294-297. 
12. Leslie, M.; Case, M. C.; Hall, A. G.; Coulthard, S. A. Br. J. Haematol. 2006, 132, 740-742.

13. Haskell, C. M.; Canellos, G. P. Biochem. Pharmacol. 1969, 18, 2578-2580.

14. Richards, N. G. J.; Schuster, S. M. Adv. Enzymol. Relat. Areas Mol. Biol. 1998, 72, 145-198.

15. Aslanian, A. M; Fletcher, B. S.; Kilberg, M. S. Biochem. J. 2001, 357, 321-328.

16. Lorenzi, P. L.; Llamas, J.; Gunsior, M.; Ozbun, L.; Reinhold, W. C.; Varma, S.; Ji, H.; Kim, H.; Hutchinson, A. A.; Kohn, E. C.; Goldsmith, P. K.; Birrer, M.; Weinstein, J.N. Mol. Cancer Ther. 2008, 7, 3123-3128.

17. Lorenzi, P. L.; Reinhold, W. C.; Rudelius, M.; Gunsior, M.; Shankavaram, U.; Bussey, K. J.; Scherf, U.; Eichler, G. S.; Martin, S. E.; Chin, K.; Gray, J. W.; Kohn, E. C.; Horak, I. D.; Von Hoff, D. D.; Raffeld, M.; Goldsmith, P. K.; Caplen, N. J.; Weinstein, J. N. Mol. Cancer Ther. 2006, 5, 2613-2623.

18. Sircar, K.; Huang, H.; Hu, L.; Cogdell, D.; Dhillon, J.; Tzelepi, V.; Efstathiou, E.; Koumakpayi, I. H.; Saad, F.; Luo, D.; Bismar, T. A.; Aparicio, A.; Troncoso, P.; Navone, N.; Zhang, W. Am. J. Pathol. 2012, 180, 895.

19. Koizumi, M.; Hiratake, J.; Nakatu, T.; Kato, H.; Oda, J. J. Am. Chem. Soc., 1999, 121, $5799-5800$. 
20. Gutierrez, J. A.; Pan, Y.-X.; Koroniak, L.; Hiratake, J.; Kilberg, M. S.; Richards, N. G. J. Chem. Biol. 2006, 13, 1339-1347.

21. Ikeuchi, H.; Meyer, M. E.; Ding, Y.; Hiratake, J.; Richards, N. G. J. Bioorg. Med. Chem. 2009, 17, 6641-6650.

22. Larsen, T. M.; Boehlein, S. K.; Schuster, S. M.; Richards, N. G. J.; Thoden, J. B.; Holden, H. M.; Rayment, I. Biochemistry 1999, 38, 16146-16157.

23. Koroniak, L.; Ciustea, M.; Gutierrez, J. A.; Richards, N. G. J. Org. Lett. 2003, 5, 2033-2036.

24. Okamura, H.; Bolm, C. Org. Lett. 2004, 6, 1305-1307.

25. Tamura, Y.; Minamikawa, J.; Sumoto, K.; Fujii, S.; Ikeda, M. J. Org. Chem. 1973, 38, $1239-1241$.

26. Johnson, C. R.; Kirchhoff, R. A.; Corkins, H. G. J. Org. Chem. 1974, 39, 2458-2459.

27. Dahl, B. H.; Nielsen, J.; Dahl, O. Nucl. Acids Res. 1987, 15, 1729-1743.

28. Garrison, A. W.; Boozer, C. E. J. Am. Chem. Soc. 1968, 90, 3486-3494.

29. Boehlein, S. K.; Nakatsu, T.; Hiratake, J.; Thirumoorthy, R.; Stewart, J. D.; Richards, N. G. J.; Schuster, S. M. Biochemistry. 2001, 40, 11168-11175.

30. O'Brien, W. E. Anal. Biochem. 1976, 76, 423-430. 
31. Ciustea, M.; Gutierrez, J. A.; Abbatiello, S. E.; Eyler, J. R.; Richards, N. G. J. Arch. Biochem. Biophys. 2005, 440, 18-27.

32. Tokutake, N; Hiratake, J.; Katoh, M.; Irie, T.; Kato, H.; Oda, J. Bioorg. Med. Chem. 1998, 6, $1935-1953$.

33. Hiratake, J. Chem. Record 2005, 5, 209-228.

34. Campbell, E. B.; Hayward, M. L.; Griffith, O. W. Anal. Biochem. 1991, 194, 268-277.

35. Manning, J. M.; Moore, S.; Rowe, W. B.; Meister, A. Biochemistry 1969, 8, 2681-2685.

36. Morrison, J. F.; Walsh, C. T. Adv. Enzymol. Relat. Areas Mol. Biol. 1988, 61, 201-301.

37. Schnizer, H. G.; Boehlein, S. K.; Stewart, J. D.; Richards, N. G. J.; Schuster, S. M. J. Biol. Chem. 1998, 38, 3677-3682.

38. Tesson, A. R.; Soper, T. S.; Ciustea, M.; Richards, N. G. J. Arch.Biochem. Biophys. 2003, 413, 23-31.

39. Boehlein, S. K.; Richards, N. G. J.; Schuster, S. M. J. Biol. Chem. 1994, 269, 7450-7457.

40. Davis, F. A. J. Org. Chem. 2006, 71, 8993-9003.

41. Jorgensen, W. L.; Chandrasekhar, J.; Madura, J. D.; Impey, R. W.; Klein, M. L. J. Chem. Phys. 1983, 79, 926-935. 
42. MacKerell, A. D.; Bashford, D.; Bellott, M.; Dunbrack, R. L.; Evanseck, J. D.; Field, M. J.;

Fischer, S.; Gao, J.; Guo, H.; Ha, S.; Joseph-McCarthy, D.; Kuchnir, L.; Kuczera, K.; Lau, F. T.

K.; Mattos, C.; Michnick, S.; Ngo, T.; Nguyen, D. T.; Prodhom, B.; Reiher, W.; Roux, B.;

Schlenkrich, M.; Smith, J. C.; Stote, R.; Straub, J.; Watanabe, M.; Wiorkiewicz-Kuczera, J.;

Yin, D.; Karplus, M. J. Phys, Chem. B 1998, 102, 3586-3616.

43. Vanommeslaeghe, K.; Hatcher, E.; Acharya, C.; Kundu, S.; Zhong, S.; Shim, J.; Darian, E.;

Guvench, O.; Lopes, P.; Vorobyov, I.; MacKerell, A. D., Jr. J. Comput. Chem. 2010, 31, 671-690.

44. Meyer, M. E.; Gutierrez, J. A.; Raushel, F. M.; Richards, N. G. J. Biochemistry 2010, 49, 9391-9401.

45. Wang, X. S.; Roitberg, A. E.; Richards, N. G. J. Biochemistry 2009, 48, 12272-12282.

46. Baker, N. A. Methods Enzymol. 2004, 383, 94-118.

47. Baker, N. A.; Sept, D.; Joseph, S.; Holst, M. J.; McCammon, J. A. Proc. Natl. Acad. Sci., USA 2001, 98, 10037-10041.

48. Holst, M.; Baker, N. A.; Wang, F. J. Comput. Chem. 2000, 21, 1319-1342.

49. Zhou, H.-K.; Gilson, M. K. Chem. Rev. 2009, 109, 4092-4107.

50. Wereszczynski, J.; McCammon, J. A. Q. Rev. Biophys. 2012, 45, 1-25. 
51. Aslanian, A. M.; Kilberg, M. S. Biochem. J. 2001, 357, 58-67.

52. Hutson, R. G.; Kitoh, T.; Moraga-Amador, D.; Cosic, S.; Schuster, S. M.; Kilberg, M. S. Am. J. Physiol. 1997, 272, C1691-C1699.

53. Srivasta, B.I.; Minowada, J. Biochem. Biophys. Res. Commun. 1973, 51, 529-535.

54. Gauduchon, J.; Gouilleux, F.; Maillard, S.; Marsaud, V.; Renoir, J. M.; Sola, B. Clin. Cancer Res. 2005, 11, 2345-2354.

55. Abbatiello, S. E.; Pan, Y.-X.; Zhou, M.; Wayne, A. S.; Veenstra, T. D.; Hunger, S. P.; Kilberg, M. S.; Eyler, J. R.; Richards, N. G. J.; Conrads, T. P. J. Proteomics 2008, 71, 61-70.

56. Hinchman, S. K.; Henikoff, S.; Schuster, S. M. J. Biol. Chem. 1992, 267, 144-149.

57. Cedar, H.; Schwartz, J. H. J. Biol. Chem. 1969, 244, 4112-4121.

58. van den Berg, H. Leukemia \& Lymphoma 2011, 52, 168-178.

59. Bradford, M. M. Anal. Biochem. 1976, 72, 248.

60. Brünger, A. T.; Karplus, M. Proteins: Struct. Funct. Genet. 1988, 4, 148.

61. Brooks, B. R., III; Brooks, C. L., Jr.; MacKerell, A. D.; Nilsson, L.; Petrella, R. J.; Roux, B.; Won, Y.; Archontis, G.; Bartels, C.; Boresch, S.; Caflisch, A.; Caves, L.; Cui, Q.; Dinner, A. R.; Feig, M.; Fischer, S.; Gao, J.; Hodoscek, M.; Im, W.; Kuczera, K.; Lazaridis, T.; Ma, J.; 
Ovchinnikov, V.; Paci, E.; Pastor, R. W.; Post, C. B.; Pu, J.-Z.; Schaefer, M.; Tidor, B.;

Venable, R. M.; Woodcock, H. L.; Wu, X.;Yang, W.; York, D. M.; Karplus, M. J. Comput.

Chem. 2009, 30, 1545-1614.

62. Darden, T.; York, D.; Pedersen, L. J. Chem. Phys. 1993, 98, 10089-10092.

63. Dolinsky, T. J.; Nielsen, J. E.; McCammon, J. A.; Baker, N. A. Nucl. Acids Res. 2004, 32, W665-W667.

64. Dolinsky, T. J.; Czodrowski, P.; Li, H.; Nielsen, J. E.; Hensen, J. A.; Klebe, G.; Baker, N. A. Nucl. Acids Res. 2007, 35, W552.

65. Pettersen, E. F.; Goddard, T. D.; Huang, C. C.; Couch, G. S.; Greenblatt, D. M.; Meng, E.C.; Ferrin, T. E. J, Comput. Chem. 2004, 25, 1605-1612.

66. Humphrey, W.; Dalke, A.; Schulten, K. J. Mol. Graphics 1996, 14, 33-38. 
Table 1 Steady-state kinetic parameters for the slow-onset inhibition of hASNS by the adenylated sulfoximine derivatives $\mathbf{1 , 5}$ and $\mathbf{6} .^{\mathrm{a}}$

\begin{tabular}{cccccc}
\hline Sulfoximine & $\begin{array}{c}\text { Nitrogen } \\
\text { Source }\end{array}$ & $K_{\mathrm{I}}(\mathrm{nM})$ & $k_{5}\left(\mathrm{~s}^{-1}\right)$ & $k_{6}\left(\mathrm{~s}^{-1}\right)$ & $K_{\mathrm{I}}^{*}(\mathrm{nM})$ \\
\hline & & & & & \\
$\mathbf{1}^{\mathrm{b}}$ & $\mathrm{L}-\mathrm{Gln}$ & $1000 \pm 200$ & $2.8 \times 10^{-3}$ & $2.6 \times 10^{-5}$ & $24 \pm 3$ \\
$\mathbf{1}$ & $\mathrm{NH}_{4} \mathrm{Cl}$ & $280 \pm 40$ & $3.0 \times 10^{-3}$ & $7.1 \times 10^{-5}$ & $2.5 \pm 0.3$ \\
$\mathbf{5}$ & $\mathrm{L}-\mathrm{Gln}$ & $490 \pm 25$ & $1.7 \times 10^{-3}$ & $2.6 \times 10^{-5}$ & $8 \pm 2$ \\
$\mathbf{5}$ & $\mathrm{NH}_{4} \mathrm{Cl}$ & $450 \pm 30$ & $7.3 \times 10^{-3}$ & $5.7 \times 10^{-4}$ & $33 \pm 5$ \\
$\mathbf{6}$ & $\mathrm{L}-\mathrm{Gln}$ & $4500 \pm 300$ & $2.0 \times 10^{-3}$ & $8.9 \times 10^{-4}$ & $840 \pm 140$ \\
$\mathbf{6}$ & $\mathrm{NH} C \mathrm{Cl}$ & $3040 \pm 80$ & $3.9 \times 10^{-3}$ & $4.5 \times 10^{-4}$ & $310 \pm 70$ \\
& & & & \\
\hline
\end{tabular}

${ }^{a}$ Reaction mixtures consisted of human ASNS ( $\left.4 \mu \mathrm{g}\right), 0.5 \mathrm{mM}$ ATP, $10 \mathrm{mM}$ L-aspartate, either $25 \mathrm{mM} \mathrm{L}$-glutamine or

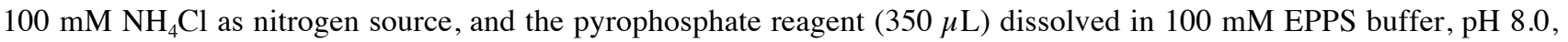
containing $10 \mathrm{mM} \mathrm{MgCl}_{2}\left(1 \mathrm{~mL}\right.$ total volume). $K_{\mathrm{I}}$ and $K_{\mathrm{I}}{ }^{*}$ are the initial and overall inhibition constant, respectively. ${ }^{35}$ ${ }^{\mathrm{b}}$ Values for the adenylated sulfoximine $\mathbf{1}$, determined at $37{ }^{\circ} \mathrm{C}$, have been published previously, ${ }^{19}$ and are included here for ease of comparison. All inhibition constants for functionalized sulfoximines $\mathbf{5}$ and $\mathbf{6}$ were determined at $25^{\circ} \mathrm{C}$. 


\section{Figure Captions}

Scheme 1. Overview of the reaction catalyzed by human glutamine-dependent asparagine synthetase, showing the structure of the $\beta$-aspartyl-AMP intermediate and the transition state for asparagine formation.

Scheme 2. Synthetic route to amino sulfoximine 5.

Scheme 3. Synthetic route to carboxy sulfoximine 6.

Figure 1. Chemical structures of adenylated sulfoximine 1, sulfamide analogue 2, sulfamate analogue $\mathbf{3}$, acylsulfamate $\mathbf{4}$, and the target set of sulfoximine derivatives $\mathbf{5}$ and $\mathbf{6}$.

Figure 2. (A) Glutamine-dependent production of $\mathrm{PP}_{\mathrm{i}}$ in the presence of the inhibitor $5(0-5 \mu \mathrm{M})$ : open squares, $0 \mu \mathrm{M}$; open circles, $0.2 \mu \mathrm{M}$; open diamonds, $0.5 \mu \mathrm{M}$; open triangles, $1 \mu \mathrm{M}$; filled squares, $2 \mu \mathrm{M}$; filled circles, $5 \mu \mathrm{M}$. (B) Ammonia-dependent production of PPi in the presence of the inhibitor $5(0-10 \mu \mathrm{M})$ : open squares, $0 \mu \mathrm{M}$; open circles, $0.4 \mu \mathrm{M}$; open diamonds, $0.7 \mu \mathrm{M}$; open triangles, $1 \mu \mathrm{M}$; filled squares, $2.5 \mu \mathrm{M}$; filled circles, $5 \mu \mathrm{M}$; filled diamonds $10 \mu \mathrm{M}$. In both figures, the solid lines represent those of best fit to Eqn. (1) (see Section 5).

Figure 3. (A) Glutamine-dependent production of $\mathrm{PP}_{\mathrm{i}}$ in the presence of the inhibitor $6(0-80 \mu \mathrm{M})$ : 
open squares, $0 \mu \mathrm{M}$; open circles, $5 \mu \mathrm{M}$; open diamonds, $25 \mu \mathrm{M}$; open triangles, $40 \mu \mathrm{M}$; filled squares, $60 \mu \mathrm{M}$; filled circles, $80 \mu \mathrm{M}$. (B) Ammonia-dependent production of $\mathrm{PP}_{\mathrm{i}}$ in the presence of the inhibitor $6(0-20 \mu \mathrm{M})$ : open squares, $0 \mu \mathrm{M}$; open circles, $2 \mu \mathrm{M}$; open diamonds, $5 \mu \mathrm{M}$; open triangles, $8 \mu \mathrm{M}$; filled squares, $15 \mu \mathrm{M}$; filled circles, $20 \mu \mathrm{M}$. In both figures, the solid lines represent those of best fit to Eqn. (1) (see Section 5).

Figure 4. (A) Cartoon representation of the homology model of the AS-B/L-glutamine/ $\beta$-aspartyl$\mathrm{AMP} / \mathrm{MgPP}_{\mathrm{i}}$ complex, rendered in Chimera ${ }^{65}$ Residues in the $\mathrm{N}$-terminal glutaminase and the C-terminal synthetase domain are colored blue and yellow, respectively. Bonds in the L-glutamine (glutaminase domain), $\beta$-aspartyl-AMP and $\mathrm{MgPP}_{\mathrm{i}}$ (synthetase domain) ligands are indicated by lines. (B) The electrostatic potential in the synthetase active site of the AS-B model rendered on the van der Waals surface of residues located within $0.4 \mathrm{~nm}$ of the $\beta$-aspartyl-AMP intermediate (Leu-232, Leu-233, Ser-234, Asp-238, Ser-239, Ser-270, Phe-271, Ala-272, Pro-279, Met-332, Ser-346, Gly-347, Glu-348, Asp-351, Glu-352, Tyr-357, Lys-376, Asp-384, Arg-387, Gly-456 and Ly-449). The potential was computed using the Poisson-Boltzmann equation ${ }^{45}$ using all atoms in the uncomplexed protein, and is visualized using the VMD software package. ${ }^{66}$ Regions of positive and negative electrostatic potential are colored blue and red, respectively. Quantitative values at $300 \mathrm{~K}$ can be computed by multiplying those shown in the legend by $0.026 \mathrm{~J} / \mathrm{mol} / \mathrm{C}$. 
Figure 5. Putative interactions between conserved residues in the ASNS synthetase active site with the four diastereoisomers of sulfoximines 5 (A and B) and 6 (C and D). Color scheme: C, grey; H, white; N, blue; O, red; P, orange; S, yellow. Image was rendered using Chimera. ${ }^{65}$

Figure 6. The effect of incubating the amino sulfoximine $\mathbf{5}$ on the proliferation of MOLT-4 leukemia cells in the presence and absence of $1 \mathrm{U}$ L-asparagine amidohydrolase (ASNase). (A) MOLT-4R cells without ASNase; (B) MOLT-4R cells with ASNase; (C) MOLT-4S cells without ASNase. Cell proliferation is defined as the number of viable cells after $48 \mathrm{~h}$ incubation expressed as the ratio to the initial number of cells $(\mathrm{t}=0)$. Error bars represent the standard deviation of triplicate experiments. 


\section{Scheme 1.}

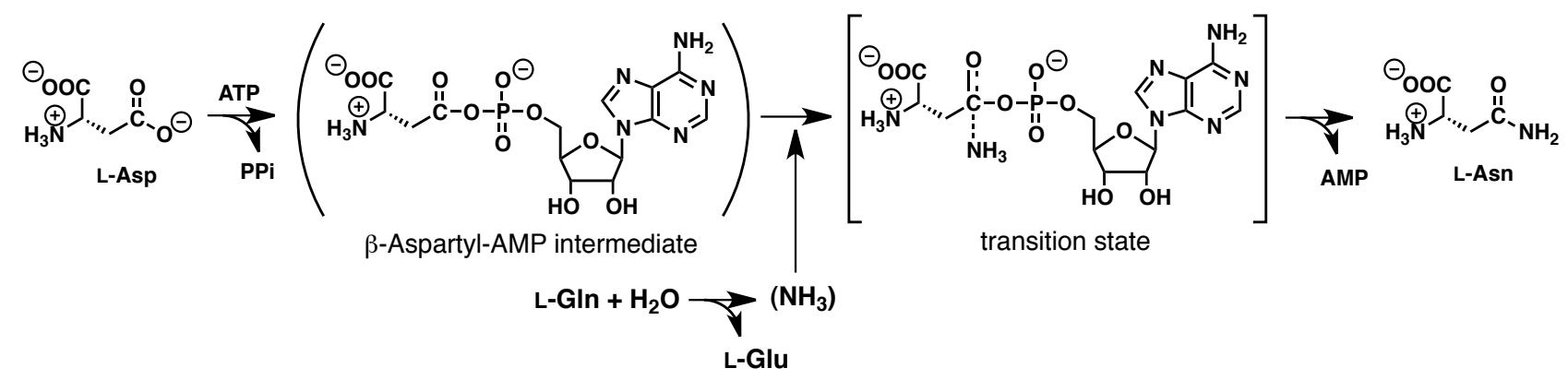


Scheme 2.
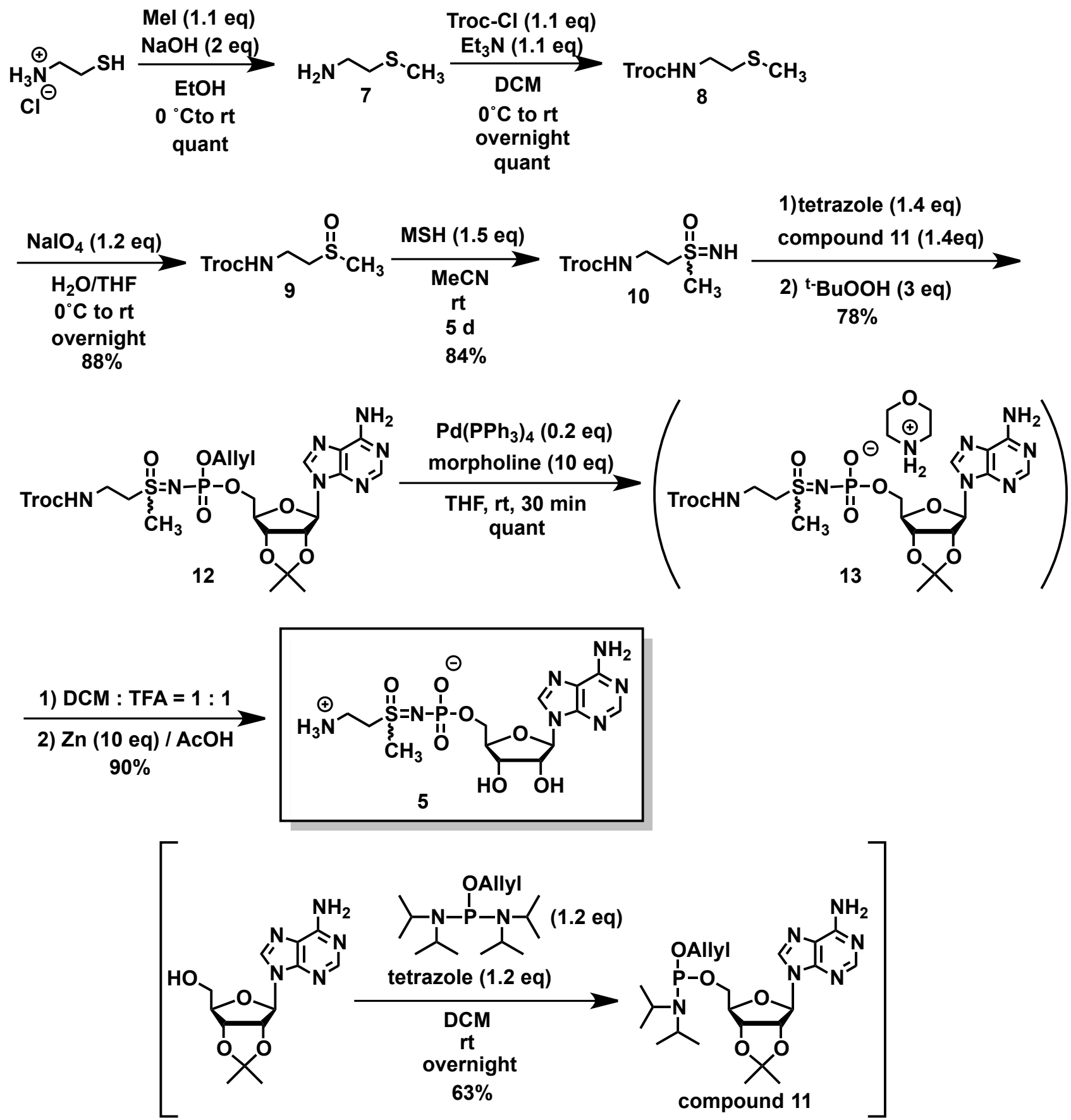
Scheme 3.
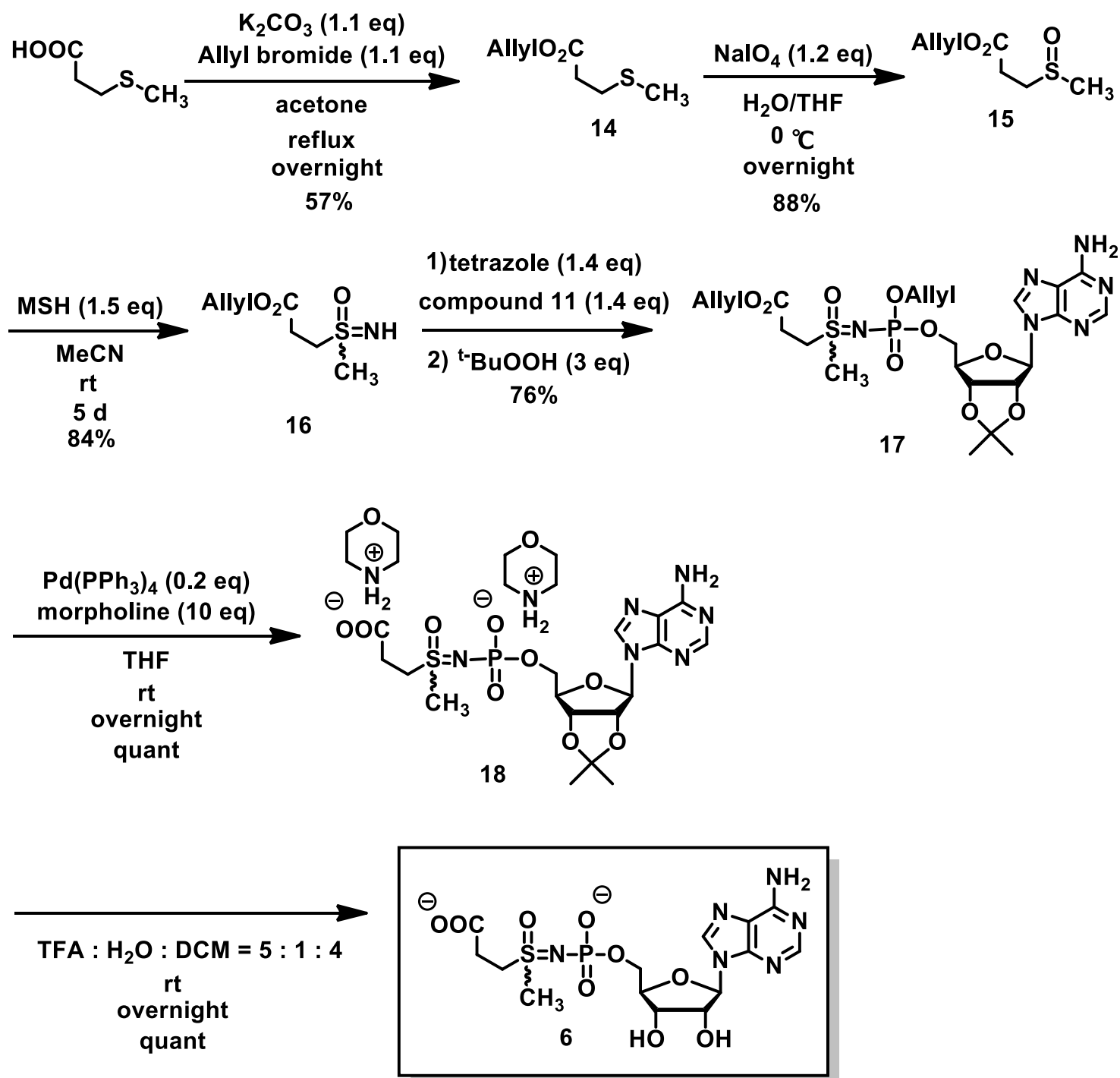
Figure 1.

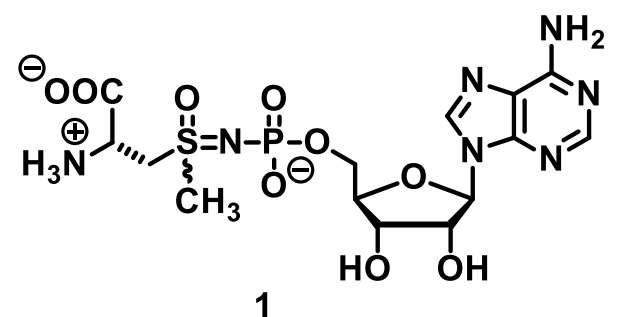<smiles>[X]CC1OC(O)C(O)C(O)C1n1cnc2c(N)ncnc21</smiles>

$$
2 \mathrm{X}=\mathrm{NH}
$$

$$
3 X=0
$$<smiles>Nc1ncnc2c1ncn2C(O)C(O)COS(=O)(=O)N[C@@H](CC(=O)O[Na])C(=O)[O-]</smiles>
4

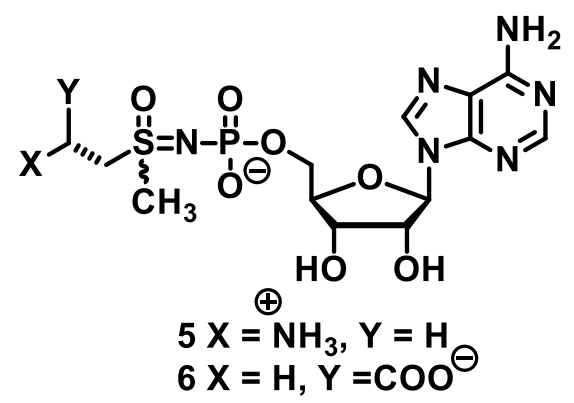


Figure 2

(A)

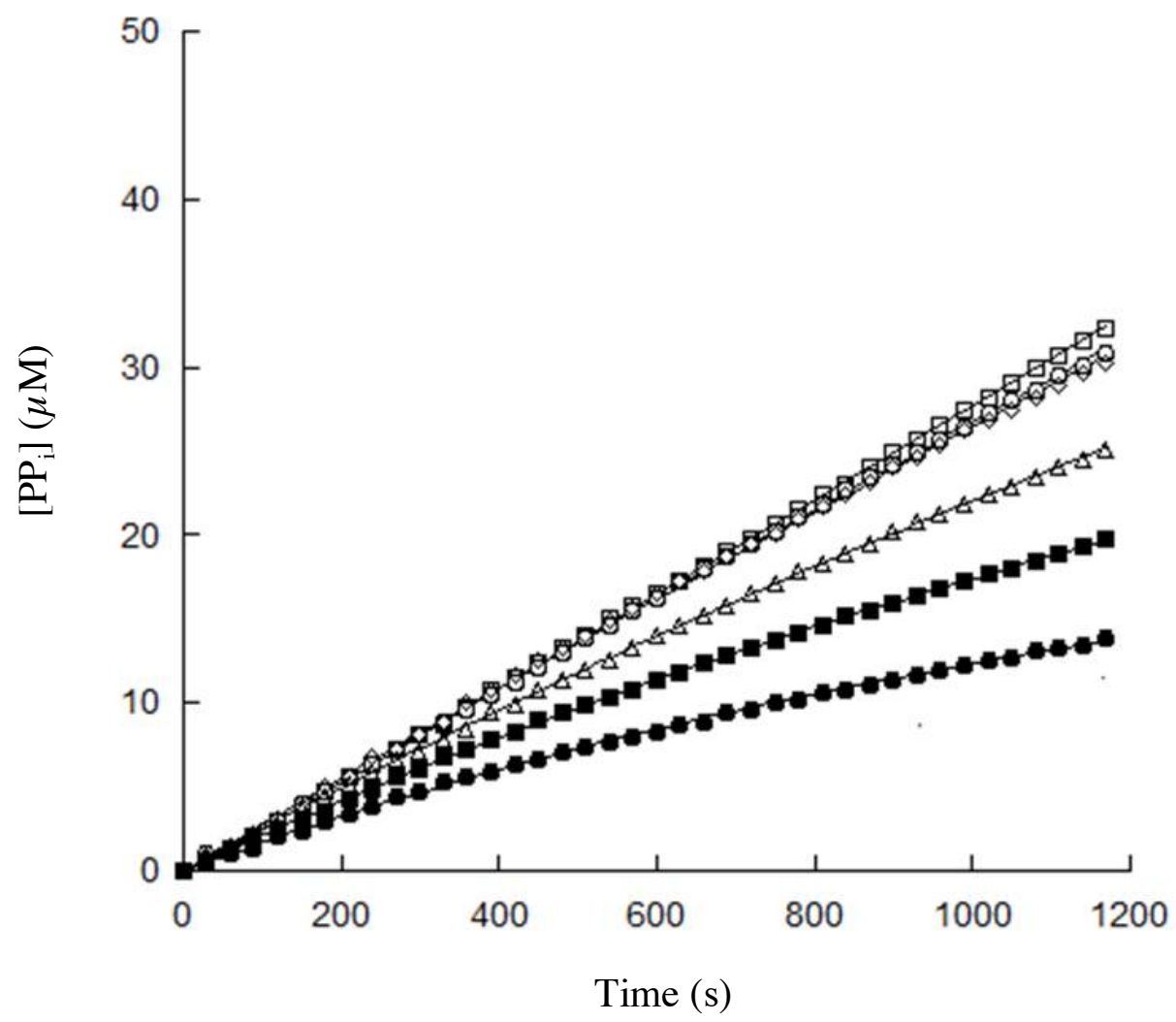

(B)

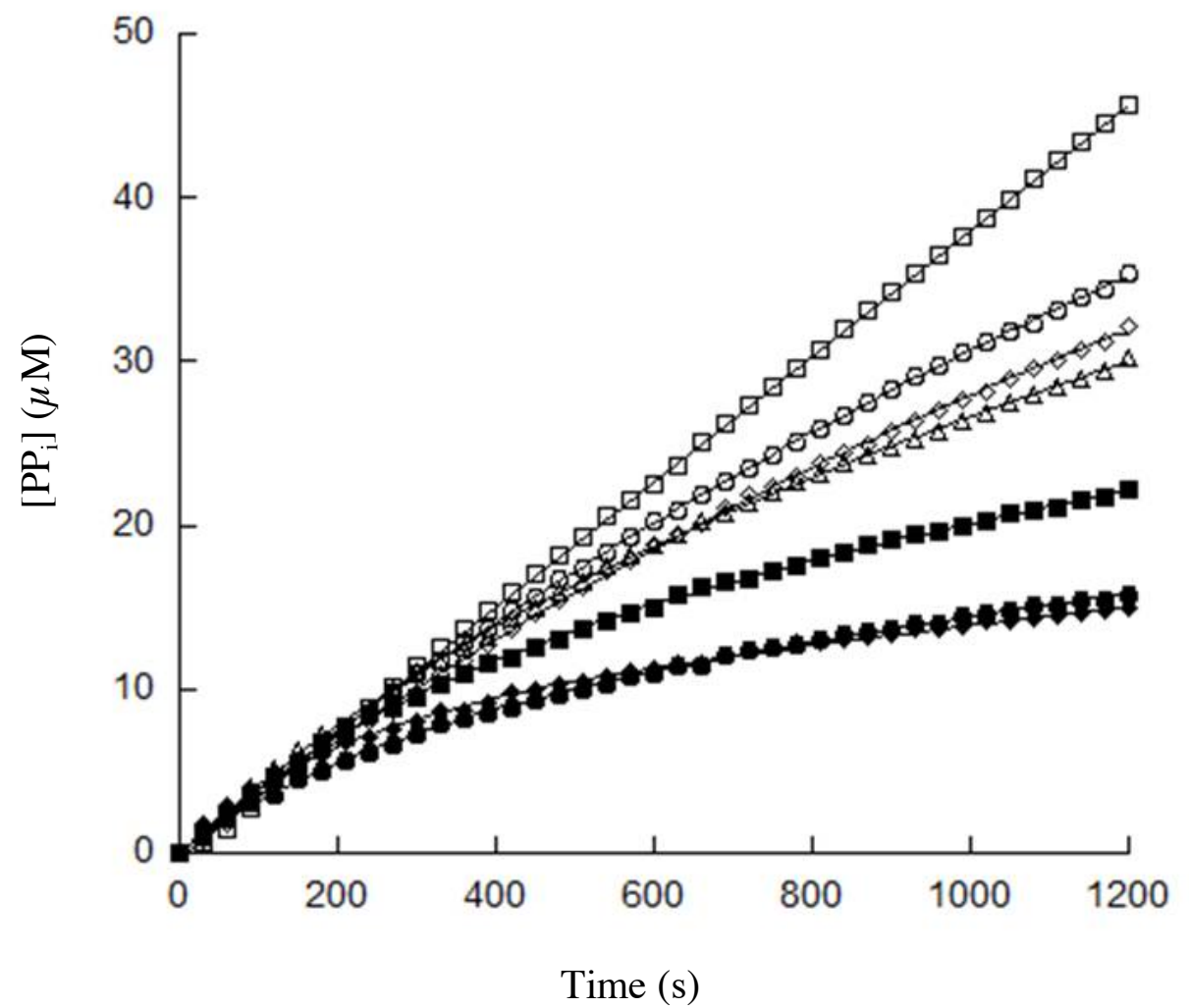


Figure 3

(A)

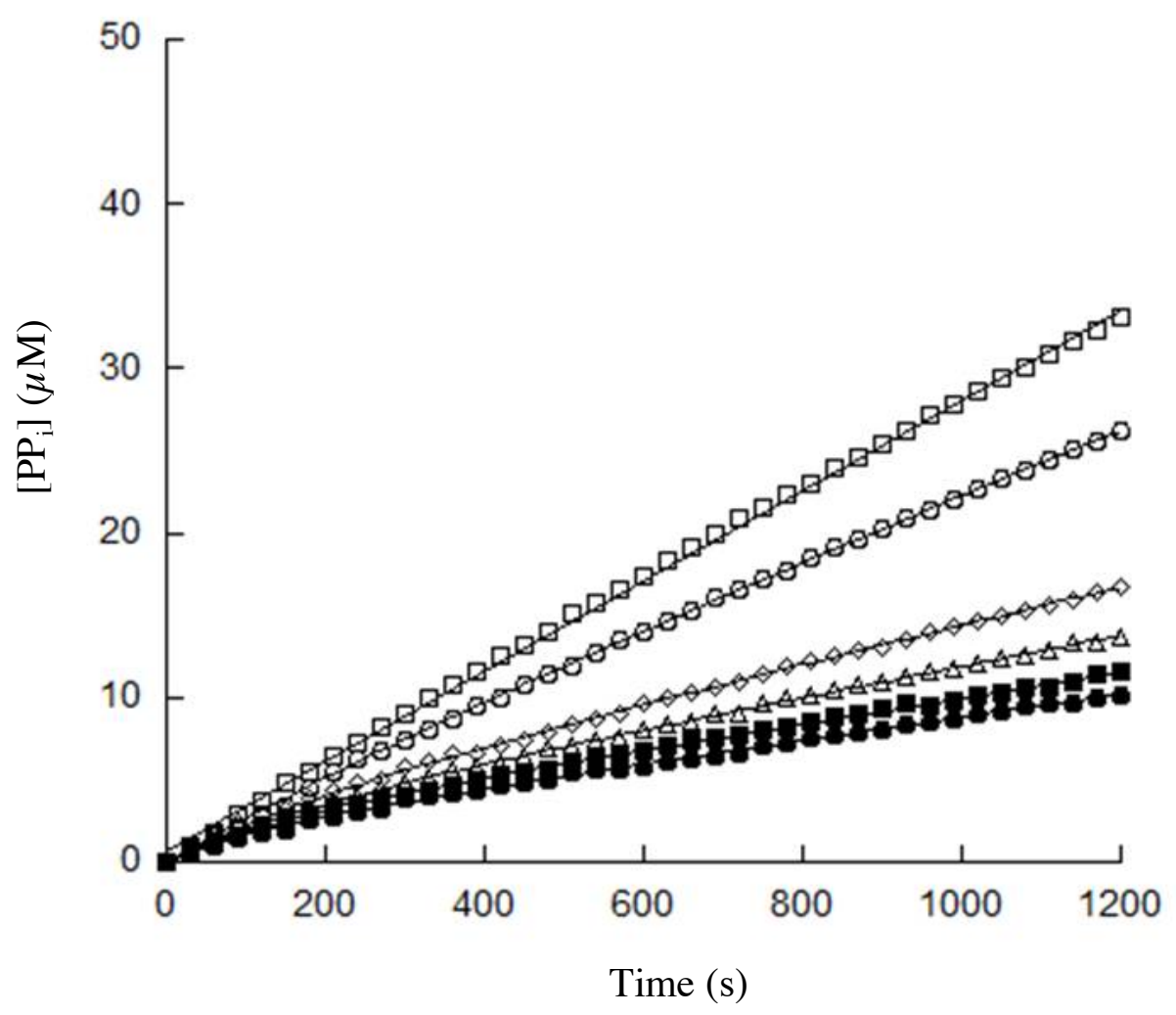

(B)

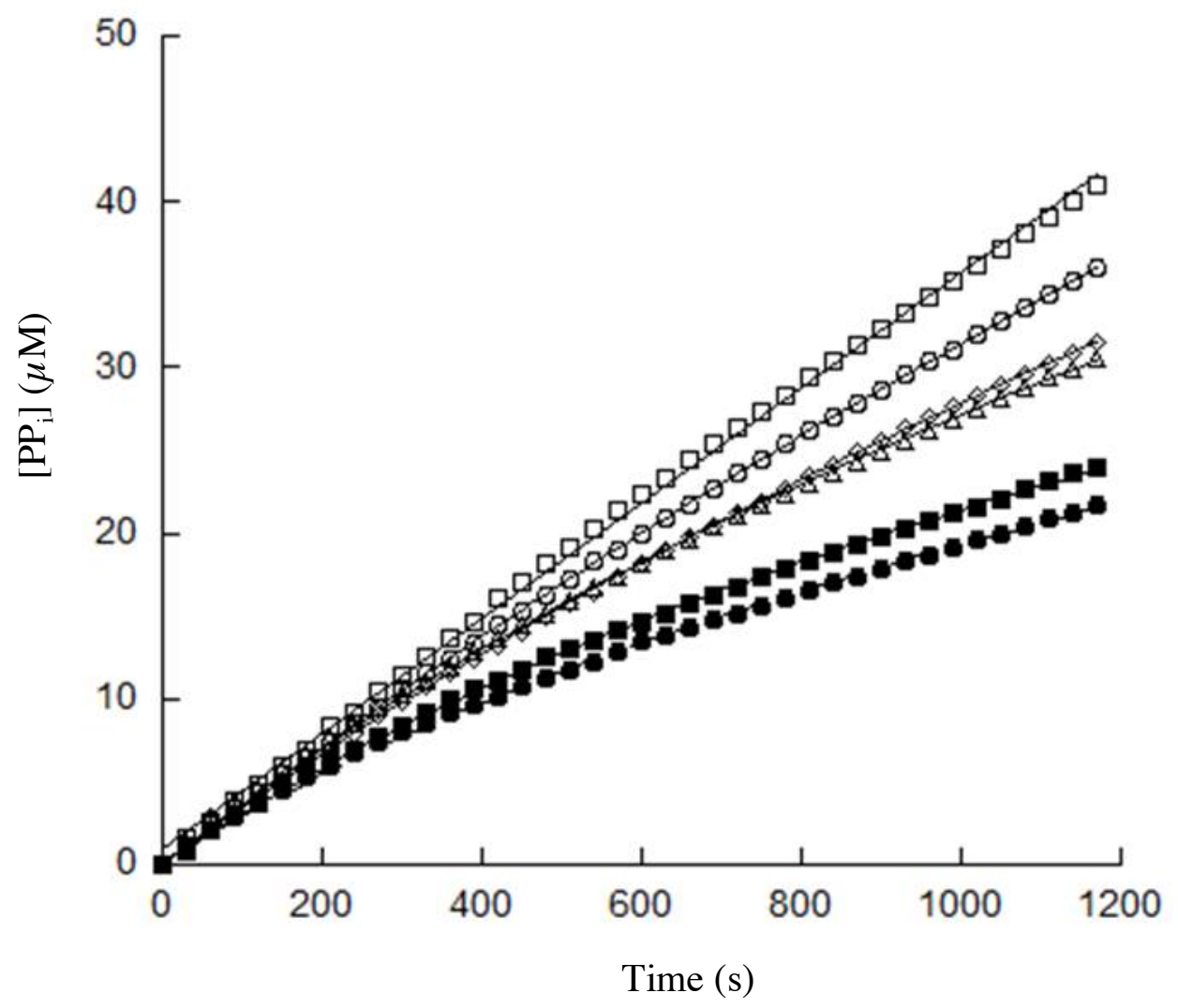


Figure 4

(A)

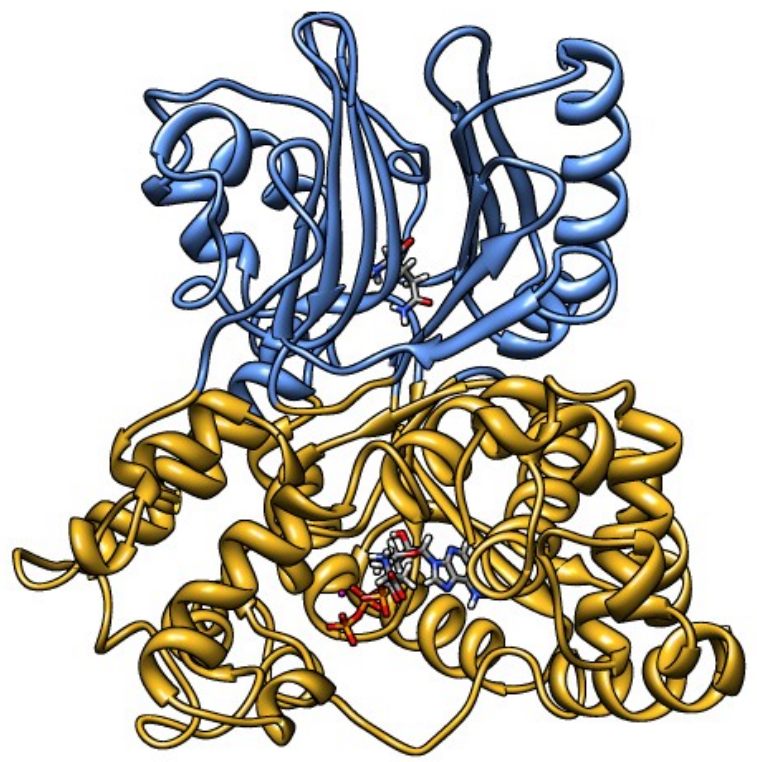

(B)

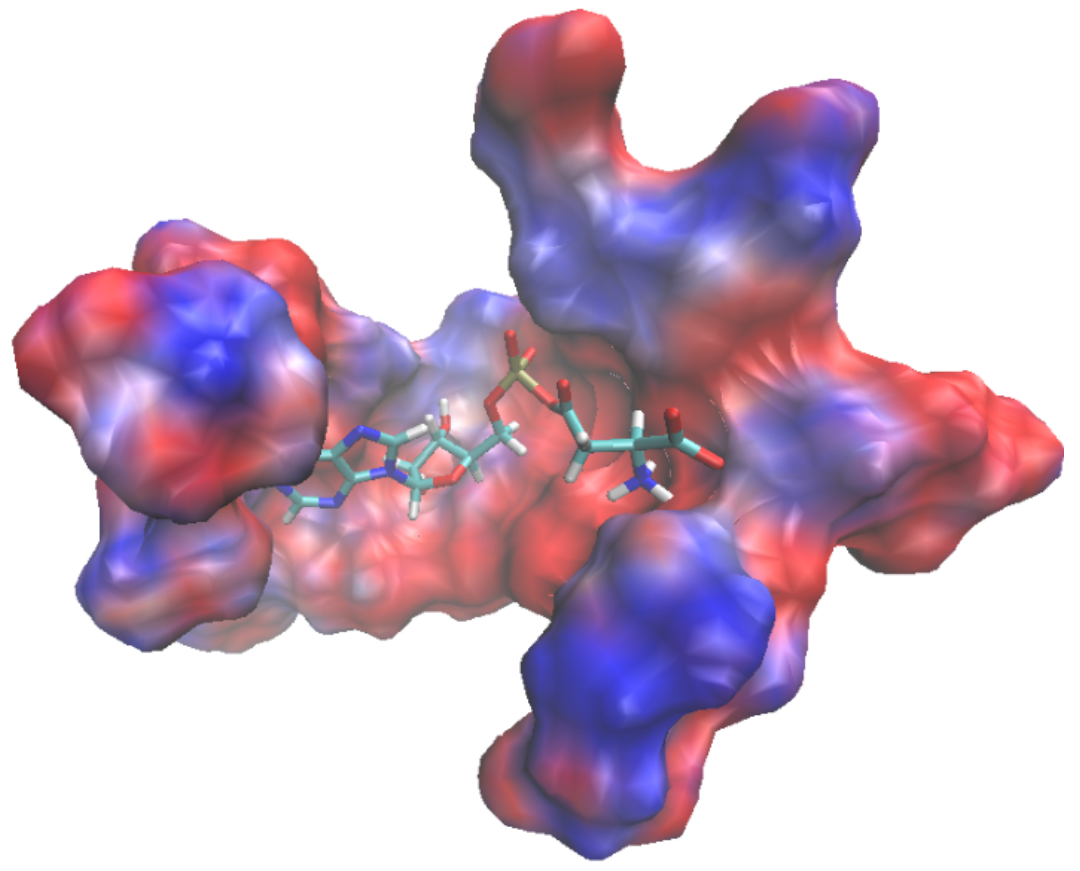


Figure 5

(A)

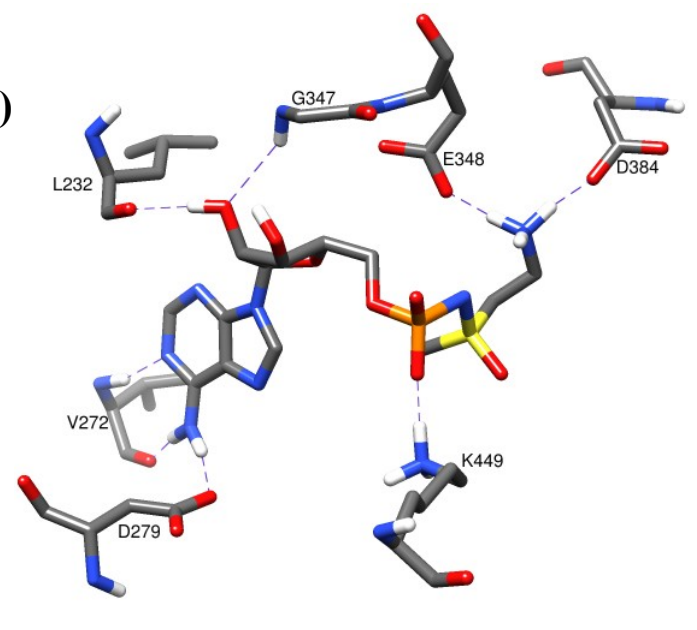

(C)

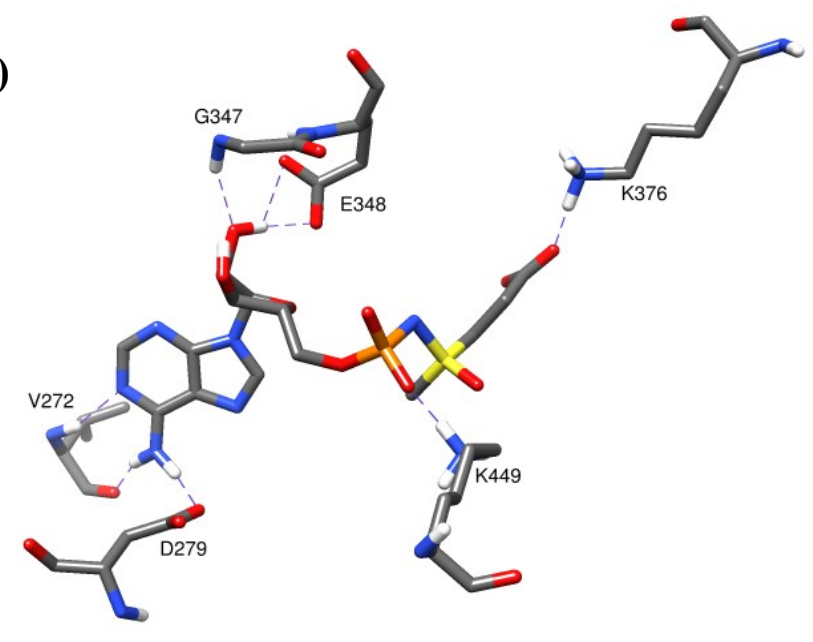

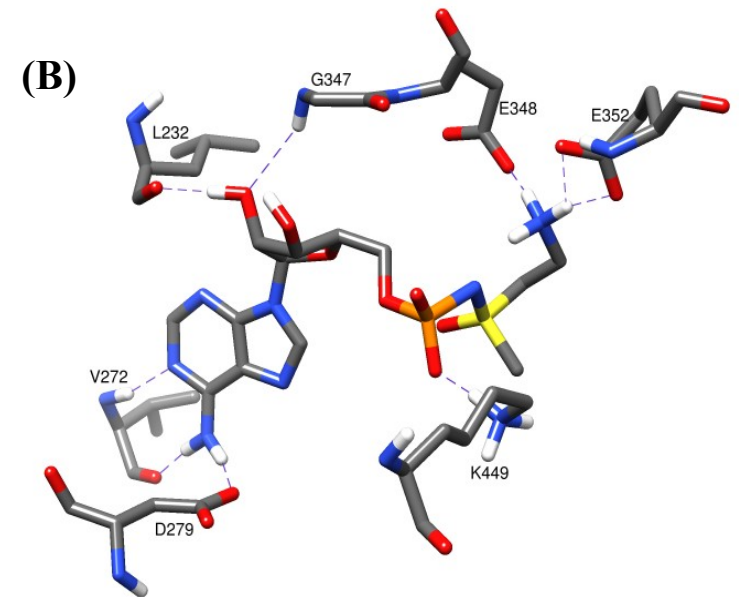

(D)

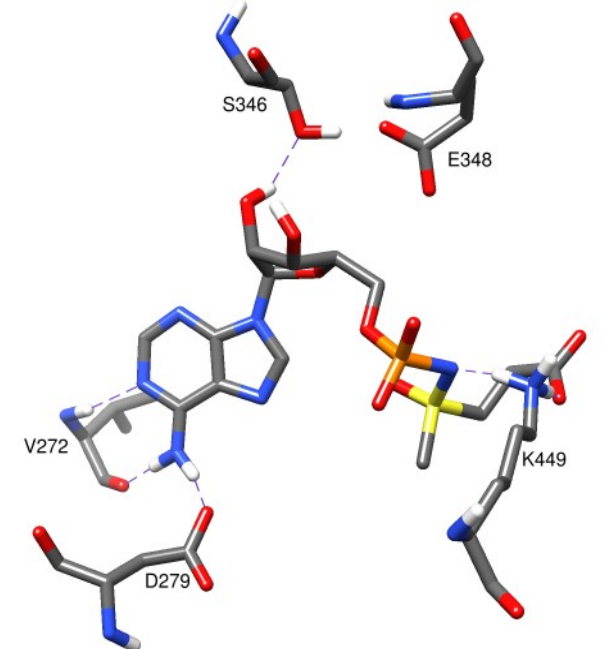


Figure 6.

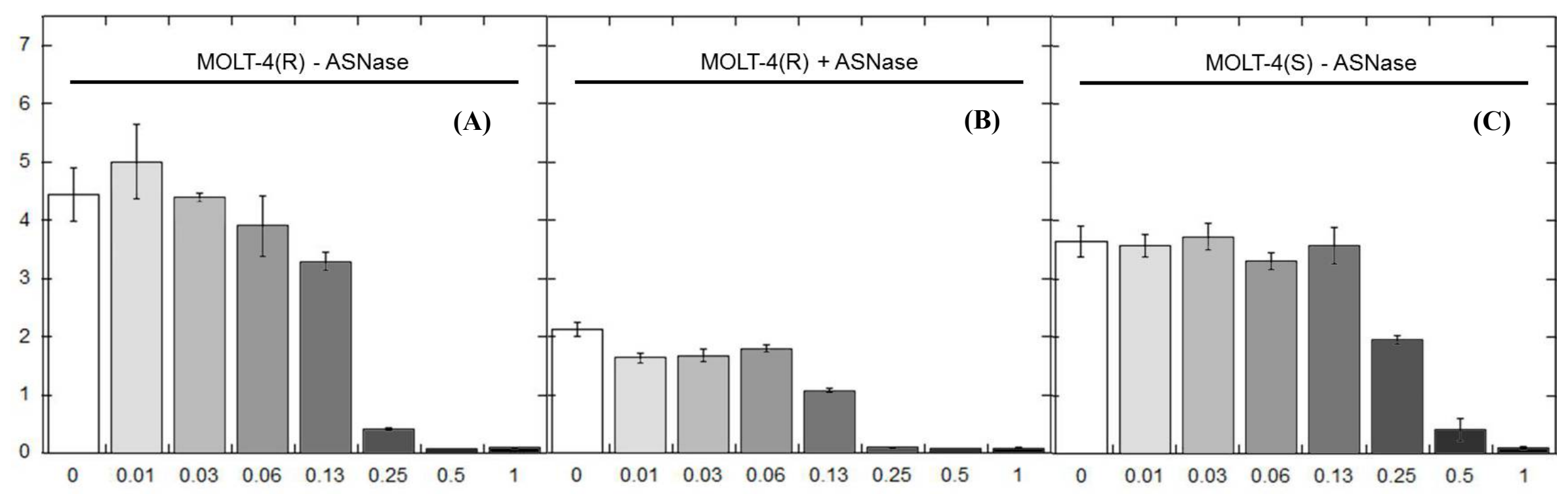

